\title{
20 \\ Kuk Stone Artefacts: Technology, Usewear and Residues
}

\author{
Richard Fullagar with Jack Golson
}

\section{Introduction}

The collection of 58 stone artefacts discussed here consists of all available examples that can be securely related to particular phases of the Kuk archaeological sequence reviewed in previous chapters of this volume. They were items from a total of some 750 registrations made in 1979 and 1980, resulting from the 1970s investigations. They comprised individual finds and stone collections from the same location, like oven stones and broken pebbles, which were grouped under one number with an accompanying letter for the constituent items. Chapter 18 provides further background to the matters discussed here, including the vicissitudes of storage and the destruction of the archaeological store in the Canberra bushfires of January 2003.

The broad aim is to document stone technology and tool function as determined from usewear and residues. Previous work has already provided evidence for the early (Phases 1-3) exploitation of starchy plants (taro, yam, palm and banana) at Kuk, with studies of starch grains and phytoliths extracted from stone tool edges (Denham et al. 2003; Fullagar et al. 2006). Evidence for later phases has not been previously published and summary stone artefact data for all phases are presented here for the first time.

The story starts in the late 1980s with Tom Loy and Barry Frankhauser, who set up a laboratory for residue analysis in the ANU Department of Prehistory. Loy recorded his examination of 87 items from the Kuk stone collection, from which he selected 58 items that showed promising evidence of usewear and residues. In the late 1990s, Tim Denham commenced $\mathrm{PhD}$ research at ANU on the early phases of the Kuk agricultural sequence, so becoming heir to the Loy selection, specifically 18 items belonging to Phases 1-3. At Denham's invitation, Richard Fullagar studied the items and there were significant results (see Denham 2003a; Denham et al. 2003; Fullagar et al. 2006). Fifty-five stones, including 54 of the promising items selected by Loy, became the subject of a report on the usewear and residue analyses that focused on 12 early phase stones, including one (K/98/217) from Denham that postdated Loy's work at ANU (Fullagar et al. 2006). In these initial studies, summarised again here, residues, including starch grains, originally identified by Fullagar and Michael Therin (then University of Sydney), were taxonomically identified by Judith Field (then University of Sydney), while phytoliths were similarly identified by Carol Lentfer (then University of Queensland). 
After the 2003 destruction of the archaeological store where the Kuk stone collection was housed as described in Chapter 18, Fullagar proceeded to analyse the rest of the Loy selection, as planned. To this he added a collection of some pieces excavated in the southeastern corner of the Kuk Station in the 1975-77 seasons. The focus was on Phases 1-3 activities in this area, although expectably materials from later phases were excavated at the same time. The overall collection had been withdrawn from the Kuk stone store for Denham's use and luckily not returned there by the time of the fire.

A further 19 pieces came from the work of Golson, Fullagar and Adam Black on the collections salvaged from the Weston fire. Damage to artefact labels and stone surfaces was considerable. Although 366 stones were selected, only 19 items in Black's final analysis could be completely read or related to the Kuk catalogue and so assigned a secure stratigraphic context. Nine artefacts from the Loy selection are also not reported here because of uncertainty in provenance.

In total, Fullagar examined 149 stones that had sound stratigraphic provenance (Table 20.1). Of these, 58 (including 49 from the original Loy selection) were identified as artefacts or possible artefacts on the basis of manufacturing and/or utilisation traces. This chapter discusses these 58 securely provenanced stone artefacts. A summary description of each artefact leads to a discussion of technology and tool function from Phase 1 to Phase 6 of the Kuk archaeological sequence.

\section{Methods}

Three broad technological and functional classes of stone artefact are identified: flaked stones, including flakes, cores and utilised fragments; grinding and pounding stones, including unmodified plant-processing tools; and ground stone implements, including axes ${ }^{1}$ and a club head. There is potential overlap between these classes because stones can be flaked or ground and then used for grinding and pounding. Moreover, functional analysis can identify episodes of recycling when, for example, a flake from a ground and polished axe might have been further modified and used as another kind of implement like a knife, a scraper or a small chisel. The starting point is to determine whether a stone is a core, a flake, a grinding/pounding stone, a ground stone implement or a piece from any of these (see Textbox 20.1).

The standard methodology adopted here has been outlined in Textbox 10.3 on tool usewear and residues (see also Fullagar 1991, 1992 and 2006). All artefacts were examined under an Olympus $^{\mathrm{TM}}$, Zeiss $^{\mathrm{TM}}$ or Nikon ${ }^{\mathrm{TM}}$ stereoscopic microscope with oblique incident light, magnifications ranging from 6x to $100 x$. All artefacts identified as tools were also examined under Olympus ${ }^{\mathrm{TM}}$ or Zeiss ${ }^{\mathrm{TM}}$ metallographic microscopes with vertical incident light, brightfield/darkfield, polarising filters and magnifications of 50x, 100x, 200x, 500x and 1000x.

1 One of the pioneers of New Guinea archaeological research, Sue Bulmer, pointed out in an early paper (1964: 247-248) that '[a]lthough axe, adze and swivel haftings were applied to recent polished blades in various parts of the highlands, there is no positive evidence as yet that there is any diagnostic feature of the blades, such as markedly asymmetrical bevelling or gripping, correlated with form of hafting, which could be used to interpret unhafted blades found in excavations'. So she grouped them together in one general class. In a paper of the same date (Bulmer and Bulmer 1964: 53), she used the terms 'axes' or 'axes-adzes' for this class. 'Axes' is used here. 


\section{Textbox 20.1: Artefact classification Richard Fullagar with Jack Golson}

Flaked stones are defined here as 'flakes', 'cores' or 'utilised fragments' (for these and other terms see Holdaway and Stern 2004). Flakes have diagnostic indications (bulbar surface, impact marks or a striking platform) that they were struck and detached from another stone, i.e. a core. A core bears the negative features of flake scars. A flake sometimes has retouch, which is in the form of distinct negative flake scars (with cones of percussion and Hertzian initiations) that were made on the flake only after it was produced and can be distinguished from use-scars. As defined here, cores cannot be flakes (see Hiscock 2007), although it might be demonstrated that the primary function of some flakes was to produce other flakes. Similarly, it might be demonstrated that the primary function of some cores was not to produce flakes but to process various animal or plant tissue.

Utilised fragments, as defined here, do not have negative flake scars diagnostic of a core, nor any unambiguous characteristics diagnostic of a flake. Utilised fragments are only identified as artefacts on the basis of usewear and residues that indicate tool use or manufacturing. Fragments themselves may be artefacts of technological processes (e.g. debris from smashing a quartz core); some may be artefacts unrelated to stone knapping technology (e.g. fire-cracked oven stones); and some may be naturally broken stones (i.e. not produced by any human activity). Contextual evidence may be able to demonstrate that some fragments are byproducts of knapping, naturally occurring rocks or manuports, i.e. stones that must have been brought on-site by people.

'Ground stone' is a potentially confusing term that refers to both 'manufacture-ground' and 'use-ground' implements, both being distinct from flaked stone artefacts (0dell 2004: 75). However, in the Australia/ PNG region, the terms 'ground stone' (e.g. edge-ground hatchet) and 'grinding stone' (e.g. seed-grinding dish) are sometimes used to make this very distinction. Here, 'ground stone implements' refers to those artefacts that have been manufactured by grinding 'for the purpose of producing an object of specific size and shape' (Odell 2004: 75). By contrast, 'grinding and pounding stones' commonly refers to unmodified cobbles (e.g. pestles and hand stones) or tabular slabs (e.g. millstones and mortars) that were used for grinding other stones like axes or processing substances like tubers, seeds, bone and wood.

However, these distinctions (between flaked stone and ground stone) and functional terminologies (for use-ground and manufacture-ground implements) remain problematic. For example, some tools are the product of several manufacturing processes-flaking, grinding, pecking and polishing. Similarly, the function of implements can be complex, involving percussion and grinding; and they can be multifunctional. Some implements ground during manufacture can be so fragmented and altered by grinding during use that traces of manufacture are difficult to identify. 


\section{The artefacts by phase}

The following section provides technological and functional descriptions for each of the 58 artefacts together with discussion of some non-artefacts. The artefacts are dealt with by phase from oldest to youngest and by artefact class: flake tools (Table 20.2), core tools (Table 20.3), utilised fragments (Table 20.4), grinding and pounding stones (Table 20.5), a ground stone club head (Table 20.6) and axes (Table 20.7).

\section{Phase 1 (c. 10,000 cal. BP)}

Four stones are catalogued in Phase 1: three flakes (Table 20.2) and one grinding and pounding stone (Table 20.5).

Artefact K/75/S178 is a schist cobble that is unmodified macroscopically, but is slightly more polished and smoothed on one side (cf. Fig. 10.T3.3). Smeared plant residues on the more pointed end (to the left in Fig. 20.1 top) include Dioscorea sp. starch granules (Fig. 20.1 bottom), most likely Dioscorea alata or pentaphylla (Fullagar et al. 2006: 601, 603). Artefact K/76/S28 is the distal end of a broken chert flake tool (Figs 20.2A and 20.3A), used for scraping and slicing starchy and siliceous plants. Artefact K/76/S29A (Fig. 20.2C) is an ignimbrite retouched wood scraper. K/76/29B is also an ignimbrite retouched flake (cf. Fig. 10.T3.2). Extracted residues include an abundance of 3-5 $\mu \mathrm{m}$ diameter starch granules (singly and in sheets) typical of Colocasia esculenta taro (Figs 20.2B and 20.3B). The tool was used to scrape wood and subsequently to slice taro.
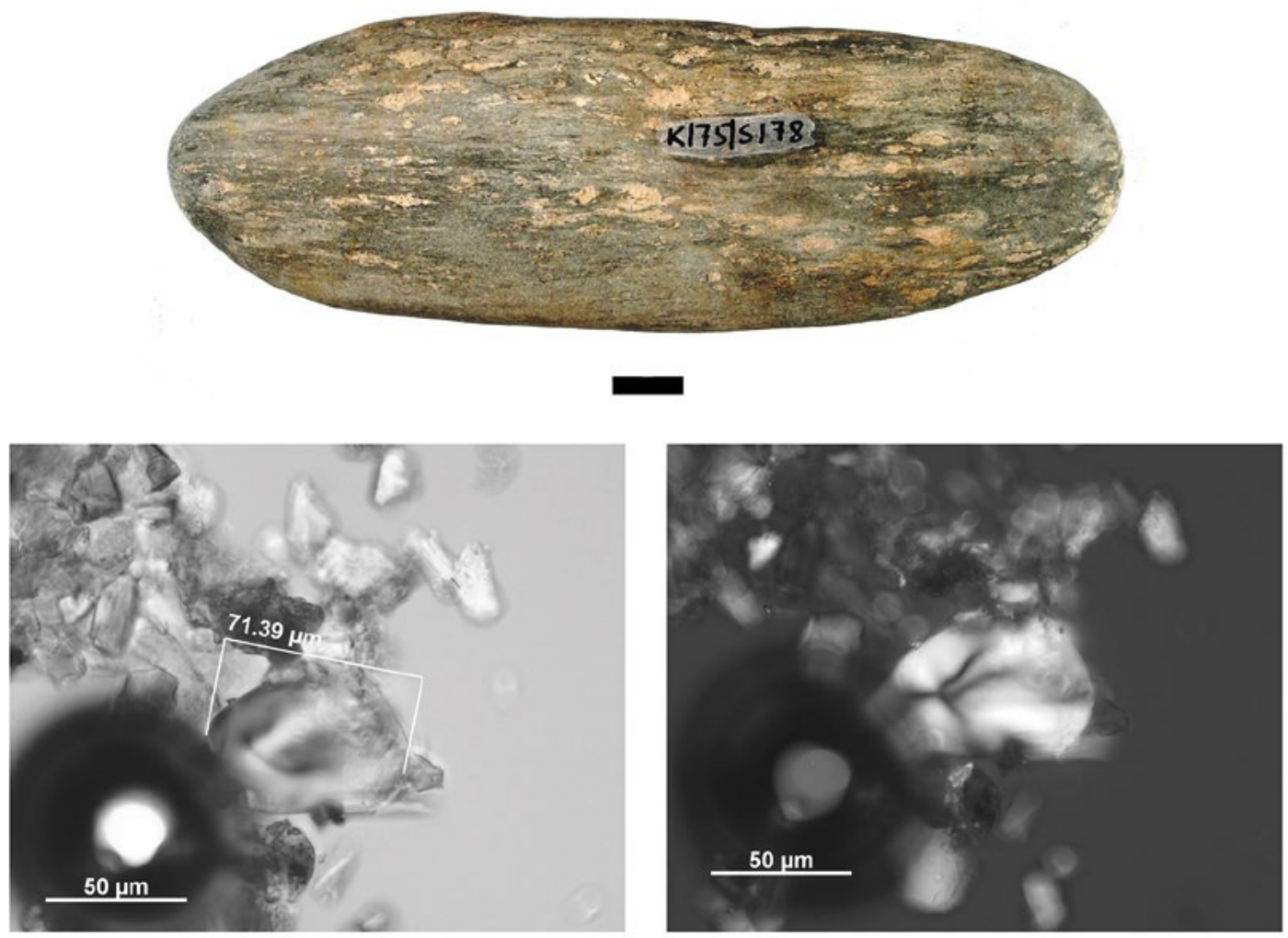

Figure 20.1 Upper image: grinding stone (pestle) $\mathrm{K} / 75 / \mathrm{S} 178$. The scale bar is $10 \mathrm{~mm}$. Lower image: large starch (Dioscorea sp.) grain from the residue extraction.

Source: Photographs by R. Fullagar and J. Field. Images reproduced with permission from Fullagar et al. (2006: 607, 609). 


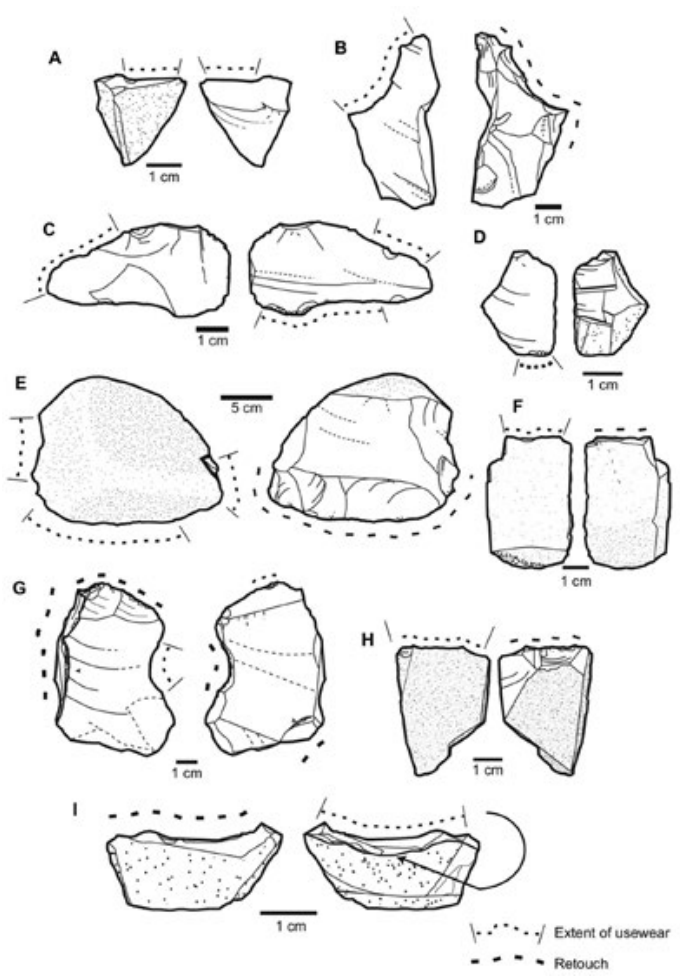

Figure 20.2 Kuk stone artefacts, (A): K/76/S28; (B): K/76/S29B; (C): K/76/S29A; (D): K/76/36; (E): K/75/S179; (F): K/77/S20; (G): K/98/217; (H): K/77/S4; (I): K/76/S19.

Source: Illustrations by R. Fullagar. Image reproduced with permission from Fullagar et al. (2006: 608).

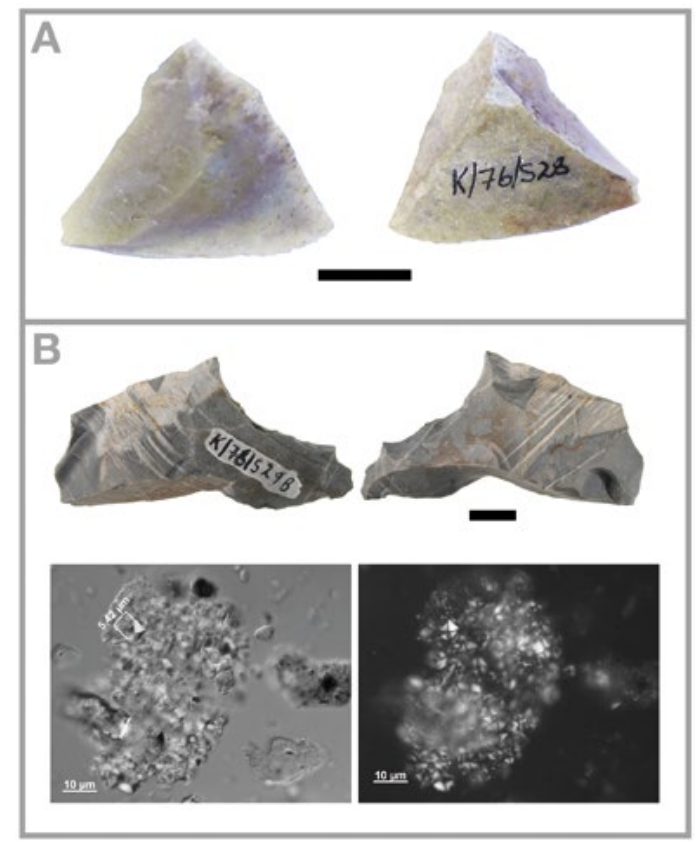

Figure $20.3 \mathrm{~A}$ : Distal portion of flake $\mathrm{K} / 76 / \mathrm{S} 28$. B: Upper image: retouched flake $\mathrm{K} / 76 / 29 \mathrm{~B}$. The scale bar is $10 \mathrm{~mm}$. Lower images: Colocasia esculenta starch grains from the edge of retouched flake $\mathrm{K} / 76 / 29 \mathrm{~B}$; lower left is under DIC (Differential Interference Contrast) and the lower right image is under cross-polarised light. The scale bars are 10 microns.

Source: Photographs by R. Fullagar and J. Field. The lower images are reproduced with permission from Fullagar et al. (2006: 606).

\section{Between Phases 1 and 2}

Seven stones catalogued from the grey clay layer between Phases 1 and 2 were examined microscopically by Fullagar (Table 20.1). Four of these seven were found to be utilised artefacts and are described below. The other three, K72/S90I, $\mathrm{K}$ and N, which were salvaged from the Weston store, are fragments of possible cooking stones found when the southern end of drain A9b/c was being dug at the base of the small hill, Blong's Nob, at the site's southern boundary (see Fig. 17.3, the hill marked B). Of the catalogued stones that were not microscopically examined, five (K/77/S35 and S36A-D) were associated with $\mathrm{K} / 77 / \mathrm{S} 34$, one of the artefacts described below, and have been discussed with S34 by Golson (2000: 234-235).

We begin the discussion of the artefacts from the grey clay with two cores (Table 20.3), one felsic volcanic, K/75/S179, and one chert, K/98/217. Both have had usable flakes struck from them and both have distinct usewear (with marked rounding) on one or more edges. Artefact K/75/ S179 (Fig. 20.4A) is a split waterworn felsic volcanic cobble core tool with unifacial flaking around most of the edge. Usewear, mostly marked edge rounding, is associated with residues (including resin-impregnated fibres) with starch grains of both Dioscorea sp. yam and Colocasia esculenta taro (Fullagar et al. 2006: 605; Fig. 20.4B here). Other unidentified starch grains are present. Phytoliths along this edge include morphotypes typical of Saccharum and Themeda. Artefact K/75/S179 was probably used to chop or mash Dioscorea yam and Colocasia taro. 
Chert artefact K/98/217 was classified as a retouched chert flake by Fullagar et al. (2006: 605). Reexamination after sonic cleaning of the surfaces indicated that neither a bulbar surface nor an impact point can be identified unambiguously. Consequently, it is described here as a core that has three identified utilised edges with usewear and with residues (notably phytoliths) that indicate it was used to scrape siliceous woody plants, grass, reeds and/or palm (Fullagar et al. 2006: 605, 607; Figs 20.5B and 20.5C here).

Artefact $\mathrm{K} 75 / \mathrm{S} 173$ is an intrusive gabbro cobble with traces of use indicating a lower grinding stone (Table 20.5; Fig. 20.6A). There is pitting in the centre that is the result of pounding or, more likely, setting up an anvil for flaking stone (Fig. 20.6B).

Golson (2000) has described artefact K/77/S34 (Fig. 20.5A) as the rim of a bowl made from tholeiitic andesite, later reclassified as tholeiitic basalt in Appendix 21.1, an igneous rock not found locally. This artefact has no clear manufacturing marks, diagnostic usewear or visible residues, but has obviously been shaped symmetrically. It is classified here as a grinding and pounding stone (Table 20.5).

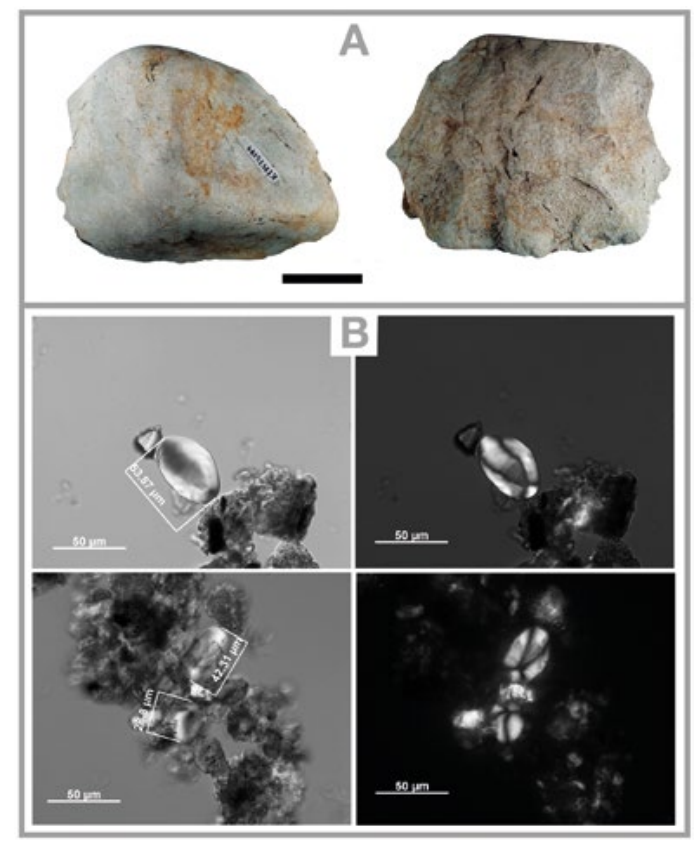

Figure $20.4 \mathrm{~A}$ : Core implement $\mathrm{K} / 75 / \mathrm{S} 179$.

B: Starch grains from Dioscorea yam (cf. D. alata and D. pentaphylla) extracted from core implement K/75/S179.

Source: A: photograph by R. Fullagar; and B: photograph by J. Field. Images reproduced with permission from Fullagar et al. (2006: 606).

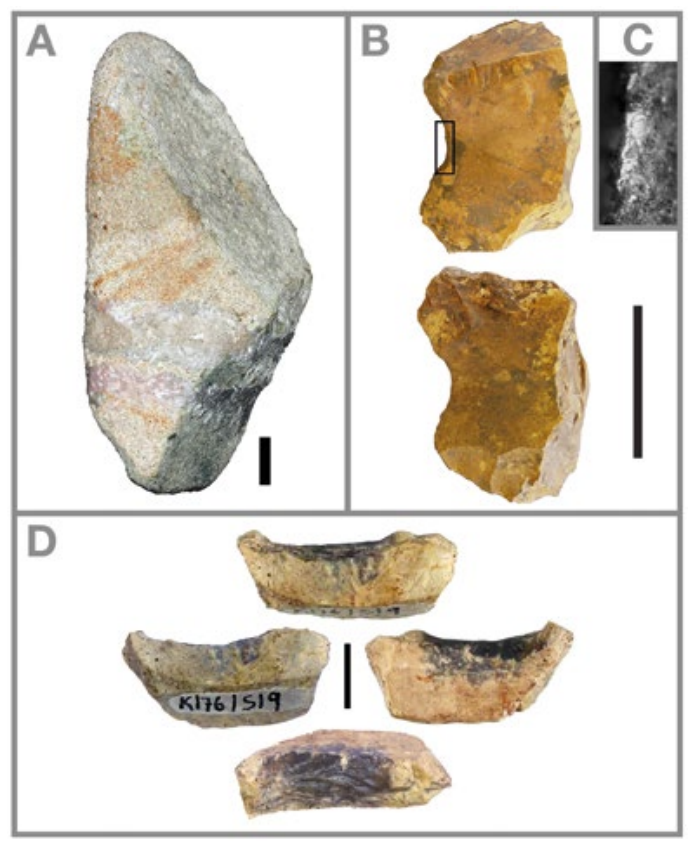

Figure $20.5 \mathrm{~A}$ : Lower grinding stone fragment K77/S34 may be the rim of a shaped bowl. The scale bar is $10 \mathrm{~mm}$. B: Core implement $\mathrm{K} / 98 / 217$. Black rectangle indicates location of most developed usewear (see also Figure 20.2). Scale bar is $50 \mathrm{~mm}$. C: Use-polish on the edge of core implement $\mathrm{K} / 98 / 217$ (near rectangle of Figure 20.5B). This polish is consistent with scraping siliceous plants such as grass, reeds and palm. Height of field is $0.3 \mathrm{~mm}$. D: Core implement $\mathrm{K} / 76 / \mathrm{S} 19$ with step scarring. The scale bar is $10 \mathrm{~mm}$.

Source: A and B: photographs by R. Fullagar; C: photographs by R. Fullagar and J. Field, with images reproduced with permission from Fullagar et al. (2006: 611); D: photograph by R. Fullagar. 


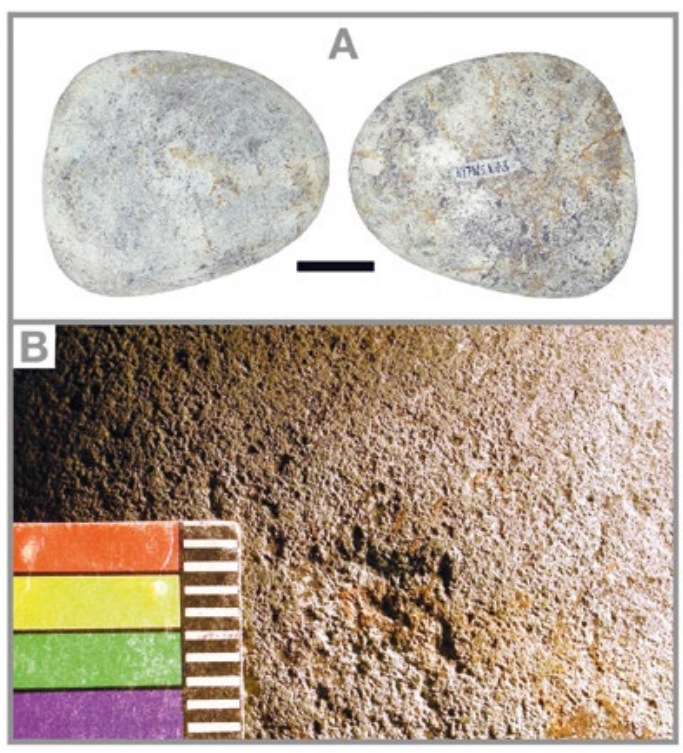

Figure 20.6 A: Lower grinding stone K75/S173. Anvil pitting is present on the surface in the centre of the left image (see Figure 20.6B). The scale bar $30 \mathrm{~mm}$. B: Detail of anvil pitting at the centre of K75/S173.

Source: Photographs by R. Fullagar.

\section{Phase 2 (6950-6440 cal. BP)}

Phase 2 has been subdivided into four contexts by Denham (2003a: vol. 1, Table 5.3): 2A, the fill of features dug at the surface of grey clay; $2 \mathrm{~B}$, the surface of the grey clay between features; $2 \mathrm{C}$, the red and white sediment (called Komun in Tables 7.1 and 7.2) sometimes present in the fill of features; and 2D, which is late Phase 2. Table 20.1 shows that 60 stones are catalogued for these units, of which 50 were examined by Fullagar, all are from Golson's excavations of the 1970s: 22 from 2A, eight from 2B, 14 from $2 \mathrm{C}$ and six from $2 \mathrm{D}$.

\section{Phase subdivision $2 A$}

There are two artefacts identified in Phase 2A, both cores (Table 20.3). Artefact K/76/S19 (Figs 20.2I and 20.5D) is a small chert core with usewear consistent with scraping bone or wood. Phytolith morphotypes (Saccharum and Palmae) suggest woodworking (Fullagar et al. 2006: 608). Artefact K/77/S4 is a chert core with slight rounding and polish (Figs $20.2 \mathrm{H}$, 20.7A and 20.7B), which indicate the scraping of soft siliceous plant tissue (Fullagar et al. 2006: 607).

\section{Phase subdivision $2 B$}

There are three artefacts identified in Phase 2B. Chert flake tool K/74/S4 (Table 20.2; Fig. 20.7C) has usewear and residues that indicate scraping. Chert flake tool K/76/ S36 (Table 20.2; Figs 20.2D and 20.7D) is a small chert flake with cortex (Fullagar et al. 2006: 607). Usewear and residues indicate that it was probably used for scraping wood or other plant tissue. Core implement K/77/ S20 (Table 20.3; Figs 20.2F and 20.7E; Fullagar et al. 2006: 607), made on a chertlike silicified volcanic rock, has one flaked edge with scarring and a thin band of polish that suggests scraping of dense wood.

\section{Phase subdivision $2 C$}

There is one artefact identified in Phase 2C, $\mathrm{K} / 77 / \mathrm{S} 17$ (Table 20.5; Fig. 20.7F). It is a heavily weathered basalt cobble (upper) grinding/pounding stone with phytoliths and Colocasia esculenta taro starch grains (Fullagar et al. 2006: 607). A bright red clay pigment or ochre is smeared on one surface.

\section{Phase subdivision 2D}

There are two artefacts identified in Phase 2D. Flake tool K/74/S28 (Table 20.2) is a very weathered felsic volcanic, but has distinct continuous bifacial scarring with edge rounding on the left lateral margin (Fig. 20.7G). Artefact K/77/S33A (Table 20.5) is a broken cobble of intrusive felsic igneous rock with crushing on small areas of the surface and along the acute edge, indicating possible use as a hammer or a pounding tool (Fig. 20.8A).

\section{terira australis 46}




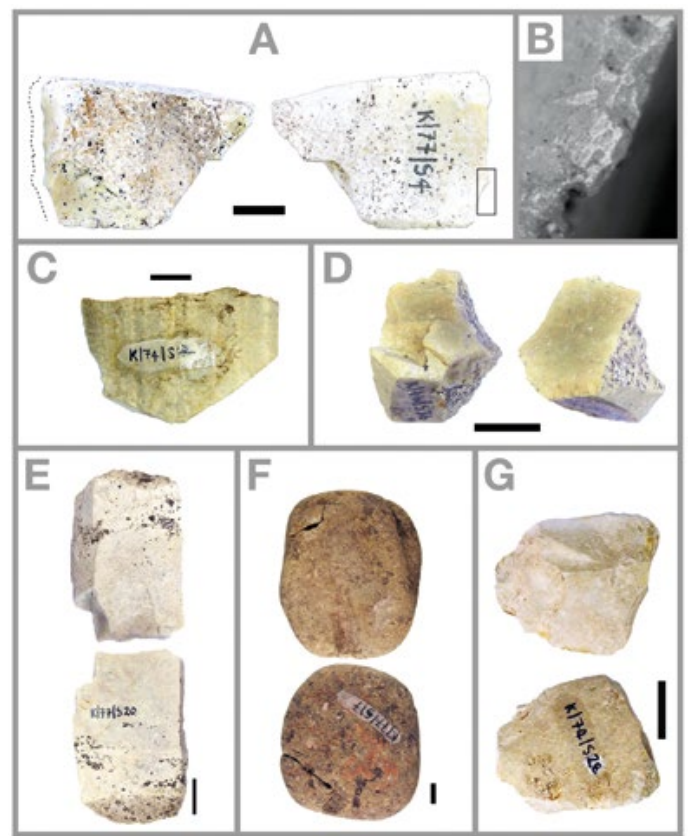

Figure $20.7 \mathrm{~A}$ : Core implement $\mathrm{K} / 77 / \mathrm{S} 4$ with scarring. Note the negative flake scars along the left margin (dotted line); at right of image: the inset indicates location of use polish shown in Figure 20.7B. B: Use-polish on $\mathrm{K} / 77 / \mathrm{S} 4$. The usepolish, rounding and scarring along this part of the retouched edge are most likely from working hard siliceous plant, probably wood (width of field is about $0.3 \mathrm{~mm}$ ). C: Flake $\mathrm{K} / 74 / \mathrm{S} 4$ has usewear on the distal margin (upper edge). D: Flake K/76/ S36 dorsal (left) and ventral (right). The utilised edge is the distal image. E: Core implement $\mathrm{K} / 77 / \mathrm{S} 20$. The utilised edge is at the upper margin of the lower image. F: Upper grinding/ pounding/hammerstone K/77/S17. G: Proximal flake K/74/S28 (bottom: ventral; top: dorsal). The utilised edge (left lateral margin) is the edge to the top of the dorsal image. Scale bar is $10 \mathrm{~mm}$.

Source: Photographs by R. Fullagar. Images B and F reproduced with permission from Fullagar et al. $(2006: 609,611)$.

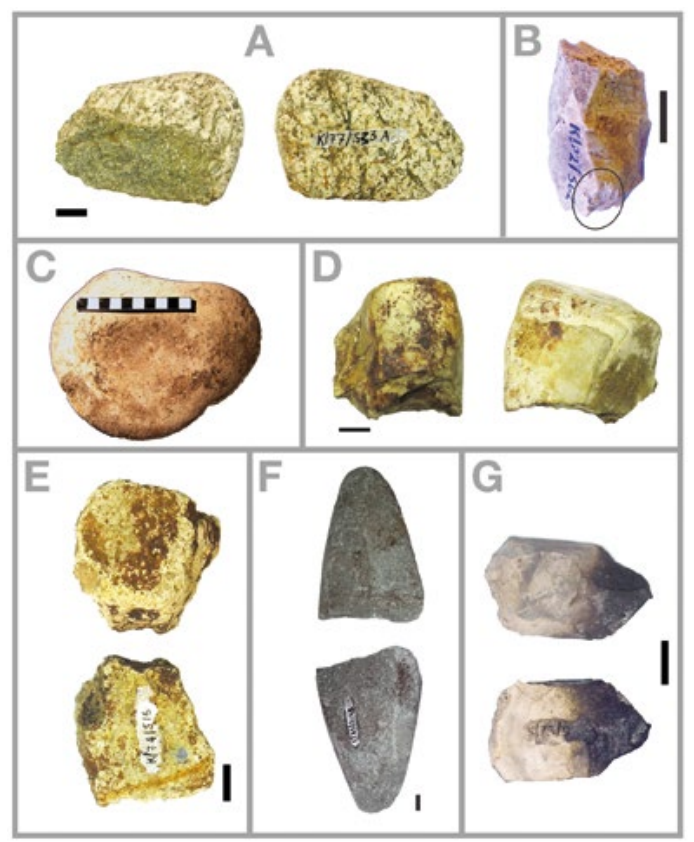

Figure $20.8 \mathrm{~A}$ : Possible grinding/pounding stone fragment $\mathrm{K} / 77 / \mathrm{S} 33 \mathrm{~A}$ has crushing on the broken acute edge and phytoliths (unidentified) were recovered from the same surface. The scale bar is $10 \mathrm{~mm}$. B: Core implement $\mathrm{K} / 72 / \mathrm{S} 62$, showing one of the utilised edges with 'retouch' (circled). C: Lower grinding stone $\mathrm{K} / 75 / \mathrm{S} 145 \mathrm{~B}$ has a natural depression (just below the scale bar) with striations and smoothing. More recent cut marks (from excavation or recent handling) are also visible macroscopically. No residues were recovered from this surface. The scale bar is $100 \mathrm{~mm}$. D: Core implement $\mathrm{K} / 74 / \mathrm{S} 15$ with overlapping step scars, red pigment and brown sediment. E: Grinding stone fragment K/74/ S16. The macroscopically visible brown residue is sediment. F: Possible axe butt fragment $\mathrm{K} / 75$ / S193. G: Flake tool K/73/S31 (bottom: ventral; top: dorsal). The distal tip has marked edge rounding. The blackening is from the Weston Creek fire. Although utilised, the precise function is uncertain. Scale bar is $10 \mathrm{~mm}$.

Source: Photographs by R. Fullagar. 


\section{Phase 2D/3 (c. 6950-2400 cal. BP)}

There are two artefacts catalogued in Phase $2 / 3$, which indicates a location in black clay where neither $\operatorname{Kim}(\mathrm{R})$ nor Baglaga $(\mathrm{Y})$ ash is present to suggest whether we are dealing with Phase $2 \mathrm{D}$ or Phase 3. Chert core tool K/72/S62 (Table 20.3) has a retouched edge and usewear with reticular polish that indicates wood scraping (Fig. 20.8B). Grinding stone K/75/S145B (Table 20.5) is a large weathered andesite cobble, slightly dished on one surface with abrasive smoothing (Fig. 20.8C). A third item, K/75/S195, is a large stone that was not removed from its field position because of its size and the lateness of the field season. No signs of working or tooluse were seen (Jack Golson, pers. comm., 1990).

\section{Phase 3 (c. 4350-2400 cal. BP)}

The 22 stones catalogued in Phase 3 (Table 20.1) were examined by Fullagar, who identified three as artefacts with signs of manufacture and use. The others are various volcanic rocks with no signs of manufacture or use, including one basalt item, K/73/S56 (from the Weston store). Stones K/77/S12A-F comprised six volcanic fragments that fit together, and probably broke apart after excavation. Some of these stones are manuports, brought on to the site for use as oven stones.

Artefact K/74/S15, a mudstone core tool (Table 20.3), has numerous overlapping step scars along one edge that is markedly rounded (Fig. 20.8D). Bright red ochre, visible macroscopically, was noted by Loy in his initial study. One unidentified starch granule and a few phytoliths were recovered from extractions. Grating or scraping ochre was the most likely task. Artefact K/74/ S16 (Table 20.5) is a grinding stone fragment made of felsic volcanic breccia with at least two smoothed surfaces (Fig. 20.8E).

Artefact K/75/S193 is a weathered volcanic stone with no diagnostic traces of use or manufacture (Table 20.7; Fig. 20.8F). However, there are striations (visible only under low magnification with low-angled light) and there is pecking near the pointed butt end. The shape in plan and crosssection suggests it may be the medial/butt piece of an axe. If it is part of a broken axe, it is the oldest axe from Kuk, and is discussed further below.

\section{Phase 4 (2000-1230/970 cal. BP)}

There are two stones catalogued as Phase 4. Both were examined and both were identified as artefacts. Artefact K/73/S31 is a felsic volcanic flake with usewear (Table 20.2; Fig. 20.8G). This flake was recovered from the Weston store and had been damaged by fire. Artefact K/74/ S19 is a tabular basalt cobble with pitting on one surface, indicating use as an anvil (Table 20.5; Fig. 20.9A).

\section{Between the end of Phase 4 and the beginning of Phase 5 (1100 years ago to $\mathrm{AD} 1250$ )}

One sandstone artefact, $\mathrm{K} / 73 / \mathrm{S} 15$, is catalogued in this context. It is a small fragment from a grinding stone damaged by fire at the Weston store (Table 20.5; Fig. 20.9B). It came from slightly above the level of Olgaboli (Q) ash in the wall of drain A11a/b, about $25 \mathrm{~m}$ south of E-W Rd 1. Olgaboli ash marks the end of Phase 4 and predates the start of Phase 5. 


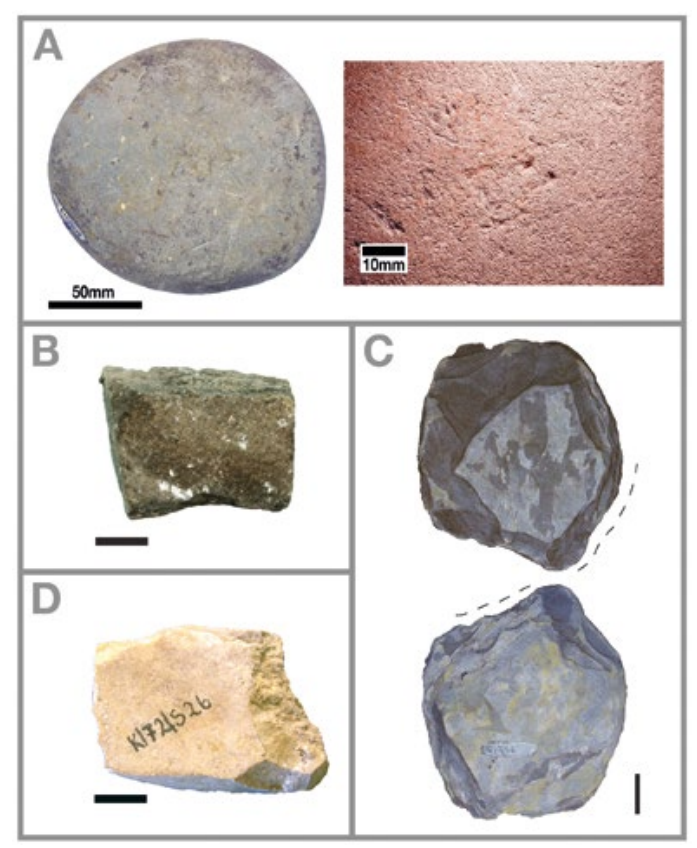

Figure 20.9 A (left): Lower grinding/pounding/ anvil stone K/74/S19; (right): Details of smoothing and pitting (cf. anvil) visible under low-angled light. B: Grinding stone fragment $\mathrm{K} / 73 / \mathrm{S} 15$. The scale bar is $10 \mathrm{~mm}$. C: Utilised fragment $\mathrm{K} / 72 / \mathrm{S} 6$, the dashed line indicates flaking. D: Core implement $\mathrm{K} / 72 / \mathrm{s} 26$, the utilised edge is at the left side. Scale bar is $10 \mathrm{~mm}$.

Source: Photographs A, B and C by R. Fullagar, photograph $D$ by $A$. Black and R Fullagar.

\section{Phases 4-6 (from 2000 years ago to $\mathrm{AD}$ 1900)}

This grouping is stratigraphically represented at the site by the 'garden soil' towards the top of the Kuk sequence (see Fig. 6.10), where the volcanic ashes that serve to distinguish the three phases in question-Kuning (Sandy 2), Olgaboli (Q), Kenta (Sandy 1) and Tibito (Z)—are not regularly preserved.

In various Phase 4-6 contexts there are 31 catalogued stones, all of which were examined (Table 20.1). Six artefacts have been identified. The 25 non-artefacts, including 19 stones from a cooking pit discussed separately below, are mostly volcanic, igneous and metamorphic rocks, with one mudstone item and one quartz crystal. Since quartz crystals are highly valued for their magical qualities among the Melpa speakers of the upper Wahgi (see Appendix 22.1), we shall look briefly at this occurrence at Kuk before dealing with the six artefacts of Phases 4-6.

The one quartz crystal mentioned above is $\mathrm{K} / 72 / \mathrm{S} 108$ of Golson's catalogue (Kuk archive), which records it as having been found in the material making up the raised floor of House B of Phase 6 (see Fig. 16.3 Inset). The fact that this raised floor material may have been dug from deposits somewhat older than Phase 6, is why the crystal is assigned to Phases 4-6, though its value in the eyes of the local population may have meant that it had been deliberately buried at the house site at the time of building. Another quartz crystal in the Golson catalogue, $\mathrm{K} / 72 / \mathrm{S} 107$, is also associated with House B, though found during the stripping of the turf and topsoil above it, which might point to its accidental as much as its deliberate association with the site. The Golson catalogue refers to the second as 'somewhat defective', whereas the first example is described as a 'fine example'.

Chert artefact K/72/S26 is a core with edgerounding, slight polish, phytoliths and starch grains (Table 20.3; Fig. 20.9D). It was probably used to scrape plant material. Artefact K/72/ S86 is a small chert core with steep flaking, like backing, opposite a more acute unretouched edge (Table 20.3; Fig. 20.10B). The use traces on both edges are similar, indicating a woodworking tool. Abundant grass phytoliths suggest a fibrous wrapping, either as a haft or perhaps some ritual attachment to empower the stone (cf. Hampton 1999: 151).

Artefact K/72/S6 is a flat slate fragment probably shaped by flaking to form a tang (cf. the 'round-bladed spade' of Bulmer 2005: 425) that has been broken (Table 20.4; Fig. 20.9C). It is not classified as a core or flake because surfaces lack the characteristics of unambiguous flake scars. Both edges have starch and phytoliths. One edge on the tang is more rounded and polished than others, which could be a result of contact with a handle. The opposite edge is also polished, with striations perpendicular to the edge. Usewear and residues suggest the tool had been 
used for chopping materials like soft fibrous plants (e.g. pandanus fruit) or possibly digging matted peat. It was found in the road drain, A $10 \mathrm{~W}$, that forms the western margin of block A10, not far from the housing area at the north end of blocks A9g and A9h (see Fig. 17.3).

Artefact $\mathrm{K} / 72 / \mathrm{S} 51$ is a long narrow basalt fragment with flake scars along one lateral margin (Table 20.4; Fig. 20.10A). Starch and phytoliths suggest it was used for cutting and scraping starchy and siliceous plant material. Artefact K/75/S30 is a glassy basalt fragment (Table 20.4; Fig. 20.10C). Both lateral margins have usewear and residues indicating intensive scraping and cutting of wood. Artefact K/77/S9 (Table 20.5; Fig. 20.11C) is a felsic intrusive igneous rock with grass phytoliths and traces of grinding and smoothing. It was previously assigned to Phase 2 (see Fullagar et al. 2006: 607), but has been reassigned to a Phases 4-6 context.

We return to the 19 stones mentioned previously and catalogued as K/75/S191A-S (Fig. 20.11A). These stones were recovered from a cooking pit dug into the fill of a Phase 3 channel in the southeastern part of the site, marked by $\mathrm{C}$ in Figure 13.7. It cannot be more precisely dated, so its contents are included in the Phases 4-6 class (Table 20.1). Interpreted as oven stones, they include six that are possibly recycled pieces of grinding stones, which fit together into two groups: A191B, J and R and K, M and P (Fig. 20.11B bottom). Similar collections of stones were excavated from similar pits both in housing areas and away from them, as in the case we are discussing. Similar stones were also widely found across the site, singly or scattered, in ditch fills and other situations. Most of these stones did not survive the 2003 fires with their catalogue numbers intact. The present collection of 19 constitutes one of three cases of which special mention is made in the text. The others, K/72/ S90I, K, N (between Phase 1 and 2 in age) and $\mathrm{K} / 77 / \mathrm{S} 12 \mathrm{~A}-\mathrm{F}$ (Phase 3 in age) have already been described.

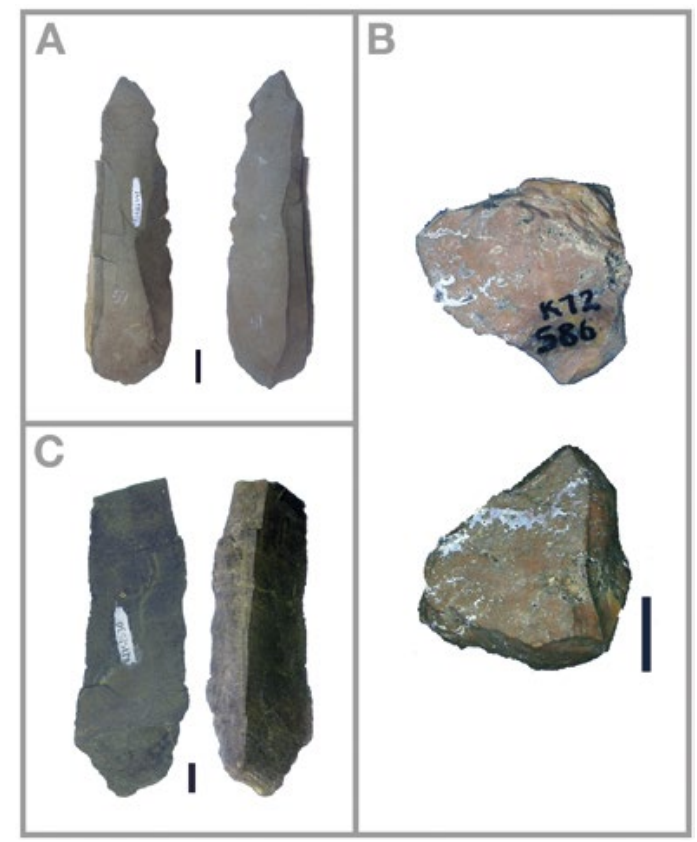

Figure 20.10 A: Utilised fragment $\mathrm{K} / 72 / \mathrm{S} 51$. Smoothing, polish and rounding are present along the edge with macroscopically visible scarring, which is most likely from use. B: Core implement $\mathrm{K} / 72 / \mathrm{S} 86$. The grey-white inclusions are chert. The platform ridge (top image) has the most developed usewear (cf. wood working). C: Utilised fragment $\mathrm{K} / 75 / \mathrm{s} 30$. Scale bar is $10 \mathrm{~mm}$. Source: Photographs by R. Fullagar.

\section{Phase 5 (AD 1250 to possibly the AD 1660s)}

Five stones are catalogued in Phase 5, of which four have signs of manufacture and/ or use (Table 20.1). K/76/S4P (Table 20.5; Fig. 20.12C) is a tabular basalt cobble with a natural bevel and triangular shape-not unlike some ooyurka of north Queensland rainforests (McCarthy 1967: 62, 70; Cosgrove 1984). The surfaces are differentially smoothed and individual grains polished in the process. The natural bevel has abrasive smoothing together with residues, the combination suggesting the grinding of soft plant tissue. The tool was found in the base of a ditch sealed by Tibito (Z) Tephra in drain E7g/h at the northern margin of Kuk Swamp on the lower slopes of Ep Ridge (for the general location see Fig. 17.3). 


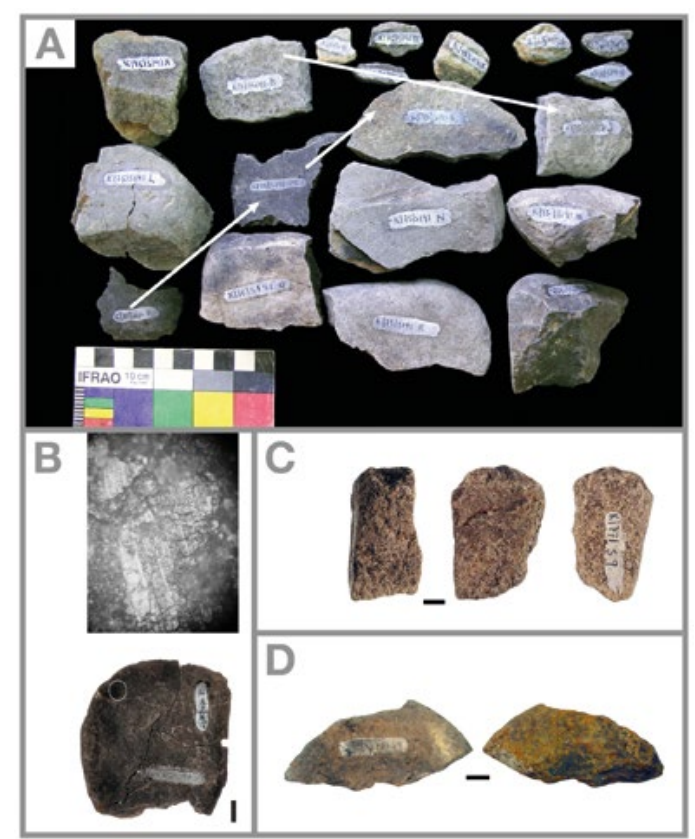

Figure $20.11 \mathrm{~A}$ : Oven stones $\mathrm{K} / 75 / \mathrm{S} 191 \mathrm{~A}-\mathrm{S}$ have no unambiguous traces of edge utilisation or grinding (but see 11B). All stones are firecracked and discoloured from utilisation in an earthen oven. B: Refitted oven stones K/75/ S191K, M and P. The white circle shows location of the top image, showing striations and smeared residue on crystal surfaces. The height of field is about $0.6 \mathrm{~mm}$. The source of these marks is uncertain, but may be post-depositional. C: Broken upper grinding stone fragment K/77/ S9, with one smoothed/polished surface facing in the far left image. D: Club head fragment $\mathrm{K} / 73 / \mathrm{S} 61$. Scale bar is $10 \mathrm{~mm}$.

Source: Photographs A, B and D by R. Fullagar; photograph C by R. Fullagar and J. Field, reproduced with permission from Fullagar et al. (2006: 609).

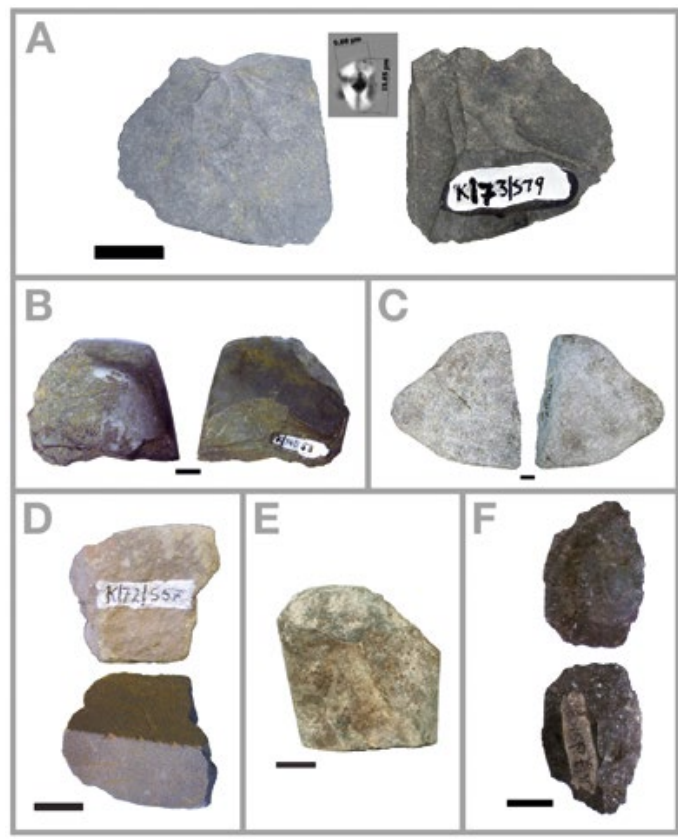

Figure 20.12 A: Ground and polished axe flake $\mathrm{K} / 73 / \mathrm{S} 79$ was recycled as a wood scraper. Starch grains were found in extractions from the working edge (centre image). The scale bar is 10 $\mathrm{mm}$. B: Ground and polished adze edge $\mathrm{K} / 74$ / s8. The scale bar is $10 \mathrm{~mm}$. C: Upper grinding stone $\mathrm{K} / 76 / \mathrm{S} 4 \mathrm{P}$. A natural facet (right image) has sustained most abrasive smoothing along the acute edge. D: Grinding stone fragment K/72/ S57. Scale bar is $10 \mathrm{~mm}$. E: Medial axe fragment $\mathrm{K} / 72 / \mathrm{S} 98$. F: Flake $\mathrm{K} / 72 / \mathrm{S} 105$. The scale bar is $10 \mathrm{~mm}$.

Source: Photographs A, B, C and D by R. Fullagar, photograph E by A. Black and R. Fullagar.

A basalt club head fragment, K/73/S61 (Table 20.6; Fig. 20.11D) was excavated from the ditch of House P, which was found side by side with House Q beneath the Phase 6 housing area at the north end of blocks A9g and A9h (Fig. 17.3 Insets 1a and 1b). The central hole was made by pecking from both sides. It was recovered from the Weston store during salvage in 2003. Artefact $\mathrm{K} / 73 / \mathrm{S} 79$ is a complete flake from a ground and polished axe (Table 20.7; Fig. 20.12A). It had been recycled as a hafted wood scraper or chisel. It was found in the ditch of House Q.

Artefact K/74/S8 is the broken blade of a ground and polished axe with asymmetrical blade bevel (Table 20.7; Fig. 20.12B). Bright spots (Rots 2003, 2010) and abrasion on lateral margins suggest hafting. Usewear and residues are typical of woodworking. The find was made above a Phase 4 ditch in the profile of drain B10e/f away from any signs of housing (see Fig. 17.3). Golson's catalogue notes that it is not securely Phase 5, rather Phase 5 or Phase 6. 


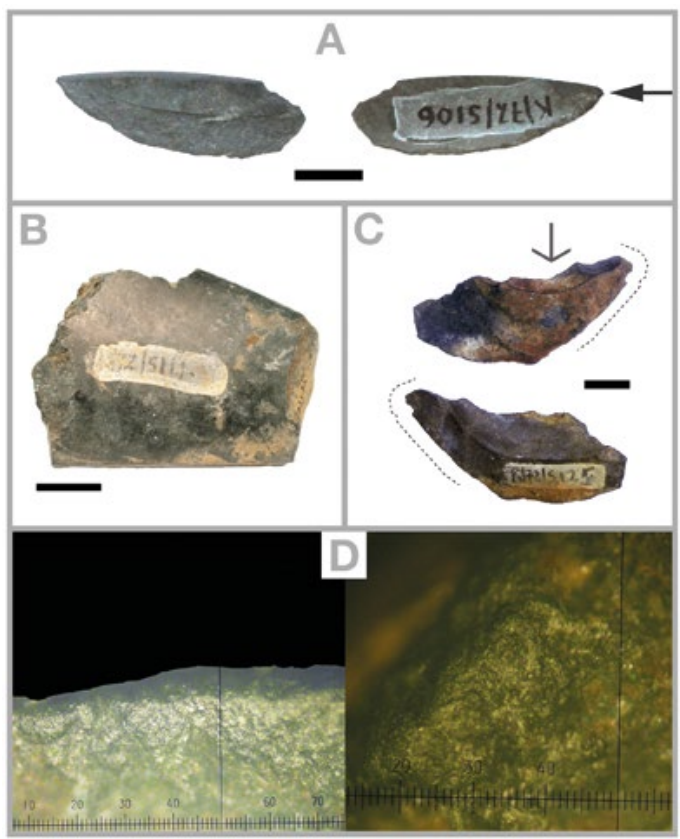

Figure $20.13 \mathrm{~A}$ : Flake $\mathrm{K} / 72 / \mathrm{S} 106$ is from an edgeground axe. At right, dorsal (original ground axe surface). The arrow indicates the most developed usewear suggesting the flake was recycled as a graving tool. The scale bar is $10 \mathrm{~mm}$. B: Medial axe fragment $\mathrm{K} / 72 / \mathrm{S} 111$. Discolouration is from fire at the Weston Creek store. The scale bar is 10 $\mathrm{mm}$. C: Flake $\mathrm{K} / 72 / \mathrm{S} 125$ (top is ventral, bottom is dorsal). For usewear within inset, see Figure 20.13D. Note retouch (dashed line) extending on to the ventral surface, along the proximal, right lateral margin. The arrow indicates the striking platform. The scale bar is $10 \mathrm{~mm}$. D: Marked edge rounding and grainy polish on flake K/72/ S125 suggesting skin scraping. Scale units are $0.01 \mathrm{~mm}$.

Source: Photographs A, C and D by R. Fullagar, photograph B by A. Black and R. Fullagar.

\section{Phase 6 (AD 1700-1900)}

Twenty-five stones were catalogued as Phase 6 and all were examined (Table 20.1). Twentyfour were identified as artefacts, with signs of manufacture and/or use (see Fig. 17.3 for location, and Fig. $17.17 \mathrm{~F}$ in relation to the men's compound on Hed Mound).

There are four flakes in Phase 6 (Table 20.2). Flake K/72/S125 is made of a volcanic stone similar to that of the ground and polished axes, but no surfaces were ground (Figs 20.13C and 20.13D). An edge has fine retouch and usewear indicating scraping of wood or skin. This flake is from the Weston store, which makes residue identification problematic. It was found at or above the floor of House $\mathrm{F}$ in block A9g in the housing area at the north end of blocks A9g and A9h. Artefact $\mathrm{K} / 73 / \mathrm{S} 72$ is possibly the distal end of a chert biface thinning flake. It has low-angled striations indicating use for cutting and slicing (Fig. 20.14B). It was found, together with much wood and cooking stone, in the south ditch of House A in block A9g of the housing area at the northern end of blocks $\mathrm{A} 9 \mathrm{~g}$ and A9h (Fig. 17.3).

Chert flake K/73/S81 was detached from a large woodworking implement (Fig. 20.15A) and was subsequently used along its distal edge for fine woodworking tasks. It was found on the floor of House A. Artefact K/77/S42, also from a housing context, is a chert bipolar flake (Fig. 20.15C) with developed polish from slicing soft siliceous plants (Fig. 20.15D). It was also found in the men's compound on the top of Hed Mound (see Fig. 17.17F), in the northeastern quadrant of the area enclosed by its perimeter ditch.

There are three cores in Phase 6 (Table 20.3). Two edges of a felsic volcanic core implement, K/73/S69 (Fig. 20.14A) from the housing area of block A9g, are flaked and all edges have usewear and residues indicating wood scraping, probably with a hafted implement. The object was found in the south ditch of House $\mathrm{A}$ in a $<2 \mathrm{~m}$ stretch that also produced the grinding stone fragment S68, with flake S72 found elsewhere in the ditch. Core K/73/ S80 (Fig. 20.14C) is from the floor of House A (the same house as flakes S72 and S81), and has been used to produce flakes. It has three used edges, one of them involved in scraping wood (Fig. 20.14D).

A fine-grained volcanic core, K/77/S58A, is too weathered to interpret tool function (Fig. 20.16A). It was found near the southwest quadrant of the men's compound on Hed Mound (cf. K/77/S42 in the listing of flakes above), just outside its perimeter ditch. 


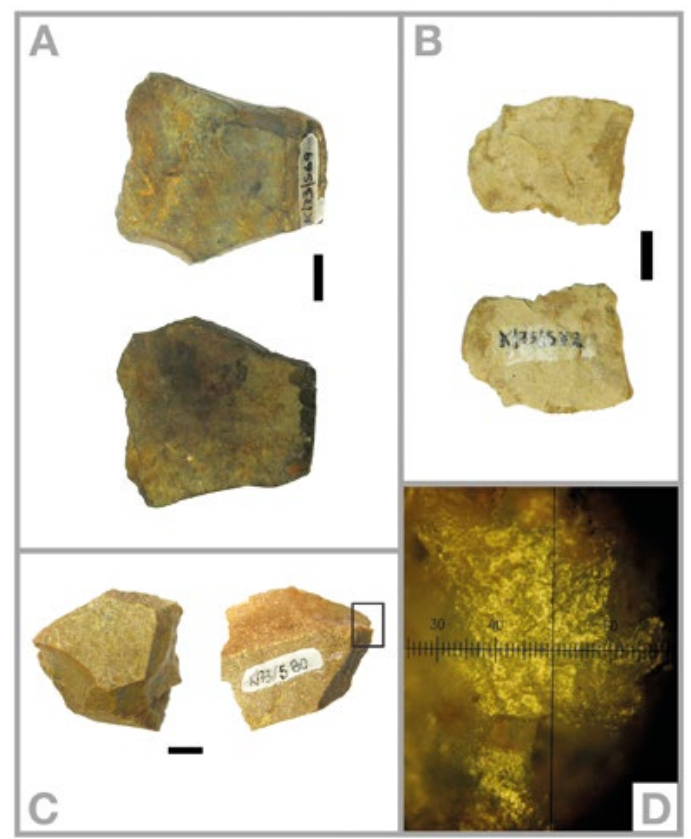

Figure $20.14 \mathrm{~A}$ : Core implement $\mathrm{K} / 73 / \mathrm{S69}$, used for wood scraping. The left and right edges have been 'retouched'. All edges have been used. B: Chert distal flake tool K/73/S72. Distal end is left. Both lateral edges have usewear. C: Core implement $\mathrm{K} / 73 / \mathrm{S} 80$. Scale bar is $10 \mathrm{~mm}$. Inset: see 20.15D. D: Polished edge of $\mathrm{K} / 73 / \mathrm{S} 80$. The scale units are $0.01 \mathrm{~mm}$.

Source: Photographs by R. Fullagar.

There are four utilised fragments in Phase 6 (Table 20.4). Artefact K/73/S65 (Fig. 20.17B) is a fragment from a larger felsic volcanic implement used to scrape wood. It is thought to be from the turf or topsoil in the vicinity of House $A$ at the northern end of block A9g, but could, however, be from House B.

Artefact K/77/S56 (Fig. 20.15F) is a chert fragment said to have been found in the southeast quadrant of the Hed Mound men's compound, but is also mentioned in connection with the ditch of the men's house, which is in the southwest quadrant. The usewear and residues indicate wood scraping. For Hed Mound finds see S42 in the listing of flakes above and S58A in that of cores, as well as the next two entries of this section and S46 in the next.

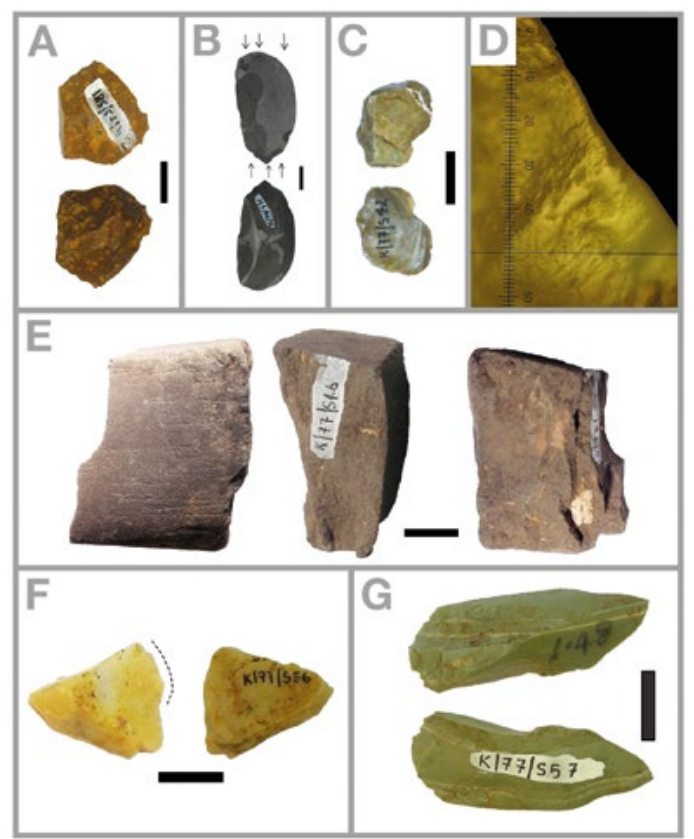

Figure $20.15 \mathrm{~A}$ : Flake tool $\mathrm{K} / 73 / \mathrm{S} 81$ (bottom is dorsal, top is ventral). Most developed usewear is on the proximal dorsal edge of the platform. The distal edge is also utilised. B: Flake tool $\mathrm{K} / 74 / \mathrm{S} 71$ was recycled from an edge-ground axe. Bottom is ventral, top is dorsal (original ground axe surface). In the top image, the lower arrows indicate location of haft wear; and upper arrows indicate location of the utilised edge of the flake tool. C: Flake $\mathrm{K} / 77 / \mathrm{S} 42$. Scale bar is 10 $\mathrm{mm}$. D: Edge rounding, striations and polish on right lateral margin of flake $\mathrm{K} / 77 / \mathrm{S} 42$. The scale units are $0.01 \mathrm{~mm}$. E: Grinding stone fragment $\mathrm{K} / 77 / \mathrm{S} 46$, possible from the butt of an axe. $\mathrm{F}$ : Fragment $\mathrm{K} / 77 / \mathrm{S} 56$. Edge scarring is indicated by the bracket. G: Ground and polished axe flake $\mathrm{K} / 77 / \mathrm{S} 57$. The scale bar is $10 \mathrm{~mm}$.

Source: Photographs by R. Fullagar.

Artefact K/77/S71 is a fragment of chert with usewear along one edge (Fig. 20.16C). Fibres suggest plant processing, while wear near the tip suggests use as an awl. It was found on Hed Mound in the northwest quadrant of the area enclosed by the perimeter ditch of the house compound. 


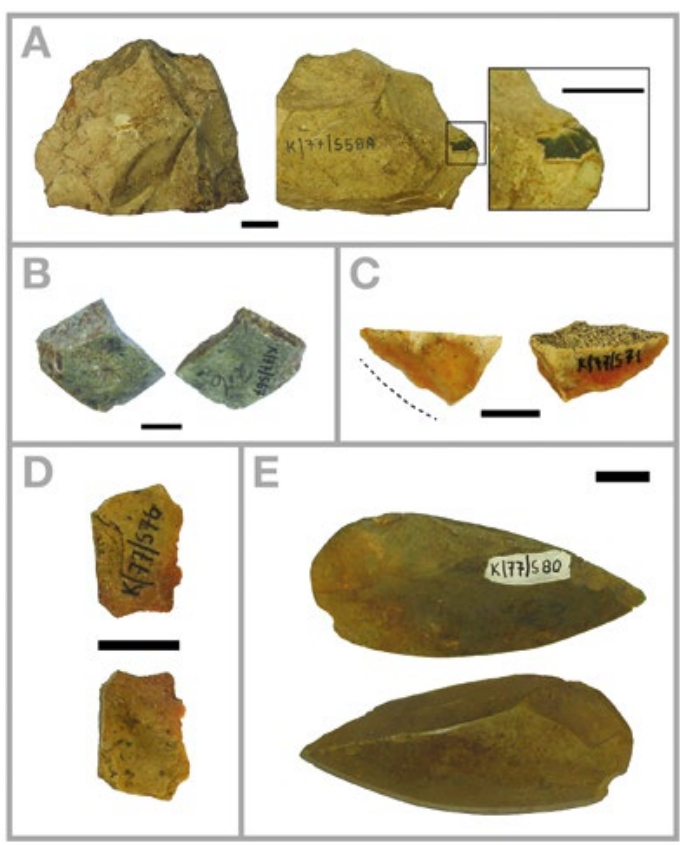

Figure $20.16 \mathrm{~A}$ : Core implement $\mathrm{K} / 77 / \mathrm{S} 58 \mathrm{~A}$. Note extreme weathering in contrast with fresh fracture scar (inset to right). B: Ground and polished axe fragment $\mathrm{K} / 77 / \mathrm{S} 67$. C: Utilised fragment $\mathrm{K} / 77 / \mathrm{S} 71$. Use-scars are present as indicated by the dashed line. D: Utilised fragment $\mathrm{K} / 77 /$ S76. E: Ground and polished adze fragment $\mathrm{K} / 77 / \mathrm{s} 80$. Scale bar is $10 \mathrm{~mm}$.

Source: Photographs by R. Fullagar.

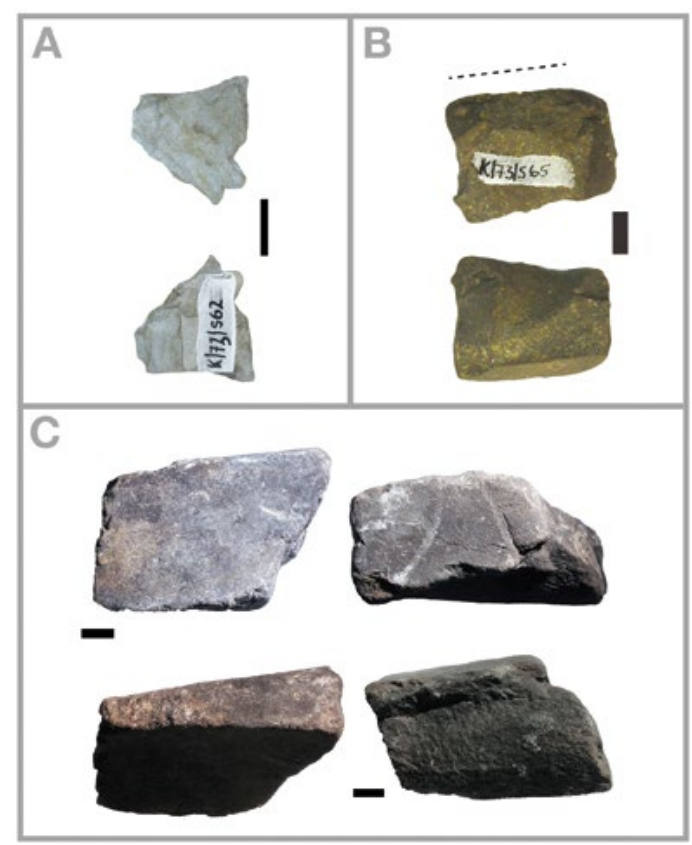

Figure $20.17 \mathrm{~A}$ : Ground edge axe flake $\mathrm{K} / 73$ / S62, recycled as a wood scraper. Bottom is dorsal ground surface, top is ventral surface with broad-bending initiation suggesting that it was detached during use. B: Utilised fragment K/73/ S65. The dotted line shows the utilised edge. C: Grinding stone fragment $\mathrm{K} / 73 / \mathrm{S} 68$ is probably part of a whetstone. Scale bar is $10 \mathrm{~mm}$.

Source: Photographs by R. Fullagar.

Artefact K/77/S76 is a chert fragment with usewear suggesting the cutting/slicing of soft tissue (Fig. 20.16D). Tom Loy attached a Hemastix ${ }^{\mathrm{TM}}$ strip to its container with a note indicating that he had taken a sample from a cracked yellow-red residue which tested positive for blood. He also noted that no blood cells could be observed. How these presumptive results link with the use of the tool is uncertain. The artefact was found in the southeast quadrant of the Hed Mound house compound.

There are three grinding and pounding stones in Phase 6 (Table 20.5). Artefact K/72/S57 is a basalt fragment with two grinding facets probably used to grind stone tool edges (Fig. 20.12D). The grinding facets are relatively flat with distinct longitudinal alignments and striations, but there are no use-related residues or developed polish. The findspot, in the surface peat at road drain B9E that marks the eastern perimeter of block B9, is about $40 \mathrm{~m}$ from the nearest house site. This is the most northerly of the line of houses at the southern end of block B9g (see Fig. 17.3 for location).

$\mathrm{K} / 73 / \mathrm{S} 68$ is a sandstone fragment with three smoothed surfaces possibly used to grind stone tool edges (Fig. 20.17C). Two surfaces are concave and the narrowest grinding surface is slightly convex. Blackened residues are the result of the Weston fires.

The find was made in the ditch of House A close to S69 (see under cores above). 
Artefact K/77/S46 (Fig. 20.15E) is a fragment of weathered metamorphosed sedimentary rock with three smoothed facets possibly used to grind stone tool edges. Grass phytoliths are common, but only one starch grain was recovered. The symmetry of the cross-section suggests that it was deliberately shaped, not unlike that of an axe or, as Loy suggested in his notes (1991, page 17), a possible 'bowl fragment'. The find was made at Hed Mound in the southwest quadrant of the area enclosed by the perimeter ditch of the men's house compound.

In Phase 6 there are 10 ground stone artefacts, including broken butt, medial and blade edge fragments $(n=5)$ and flakes $(n=5)$ (Table 20.7). Artefact K/72/S98, recovered from the Weston store after the fire, is a medial and butt fragment of a ground and polished axe (Fig. 20.12E). The tool stone is basalt. The piece was found at the southern boundary drain some $60 \mathrm{~m}$ east of N-S Rd 4, with no evident housing area nearby (see Fig. 17.3 for location).

Flake K/72/S105 has been damaged by the Weston fires. The flake, detached from the margin of an axe blade, has numerous scars with step terminations along the proximal dorsal edge (Fig. 20.12F). The thin distal edge has usewear and residues indicating subsequent use as a knife for cutting plant tissue. The piece was found in topsoil in the vicinity of House B in block A9g in the housing complex at the northern end of this block and of block A9h (Fig. 17.3 for location).

Artefact K/72/S106 (Fig. 20.13A) is a basalt flake from the medial edge of a ground and polished axe, probably an asymmetric blade bevel. The flake has been subsequently ground on the ventral edges and used for scraping and engraving wood. It was found in the same location as flake K/72/ S105. Axe fragment K/72/S111(Fig. 20.13B) was excavated in block A9h at the bottom of the ditch of the men's house there (Fig. 17.3 at ' $x$ ' and Fig. 17.9). There are neither utilised edges nor evidence of recycling after the tool was broken. The piece was stored at Weston and there is staining and cracking damage from the fires.

Flake K/73/S62 was probably detached during use from a ground and polished axe (Fig. 20.17A). The flake had been subsequently used along the distal edge as a wood scraper. It was found in the topsoil near House A in the complex at the northern end of blocks A9g and A9h (Fig. 17.3), which is also a possible locality for the discovery of utilised fragment K/73/S65. K/74/S71, from near a house ditch on drain A12b/c, is a flake from the medial part of an axe possibly broken during use. The flake was ground again to make a small wood scraper or chisel (Fig. 17.15B). The piece had probably been thrown out on the side of the drain when this was being dug across the line of the house ditch (Fig. 17.3).

Artefact K/77/S57 is from the medial part of a ground and polished axe, close to the original working edge (Fig. 20.15G). After detachment it was used for wood scraping/adzing or engraving. It was found in the southeast quadrant of the area on top of Hed Mound enclosed by the perimeter ditch. Artefact K/77/S67 is a felsic volcanic fragment from the working edge of an axe that probably broke during use (Fig. 20.16B). Along the worked edge are residues and usewear typical of axe blades. The findspot was towards the northwest corner of the area enclosed by the perimeter ditch of the Hed Mound house compound.

Artefact K/77/S80 is a basalt fragment from the used blade edge of a ground and polished axe with asymmetrical blade bevel (Fig. 20.16E). The fragment has been reshaped, ground on fresh surfaces and rehafted at the more pointed end to make a small wood scraper. It was found in the northeast quadrant of the enclosed area on the top of Hed Mound. Artefact K/77/S81 is a nearcomplete basalt ground and polished axe (with asymmetric blade bevel) with typical usewear and residues from woodworking. It is considerably worn and was reworked by flaking to maintain a symmetrical shape (Fig. 20.18). It was found in the northeast quadrant of the Hed Mound house compound. 


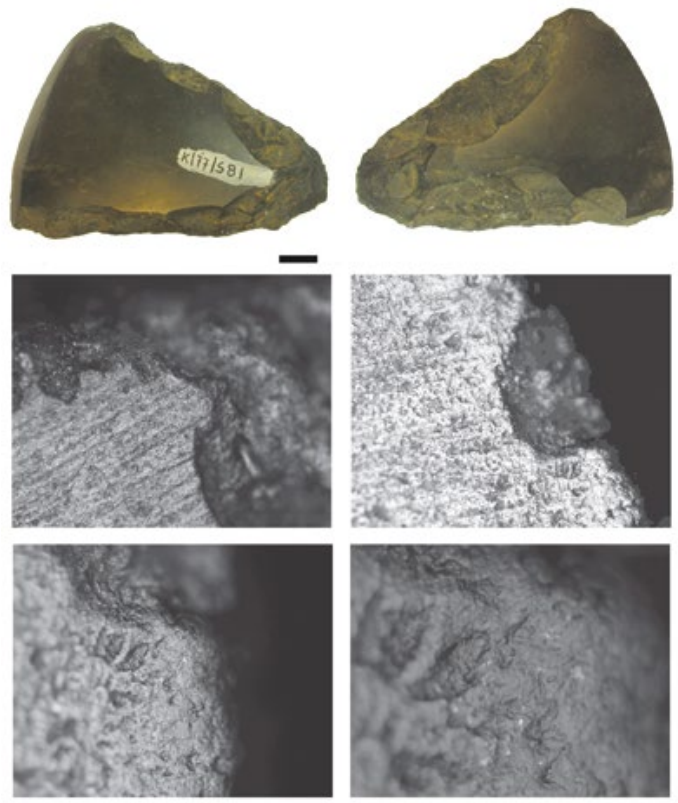

Figure 20.18 Top: ground and polished axe $\mathrm{K} / 77 / \mathrm{S} 81$ (with asymmetric blade bevel); bottom: images with microscopic polish detail at increasing magnifications from left to right and down the page (x50, x100, x200 and x500).

Source: Photograph by R. Fullagar.

\section{The artefacts discussed by class}

Stone artefacts are present but rare in each phase, with notably more in Phase 6 (Table 20.1). The artefact frequencies are far too low within phases to permit statistical analysis. The two most common artefact classes in Phases 1-3 are those including flake tools (Table 20.2) and core tools (Table 20.3) on the one hand, and grinding/pounding stones (Table 20.5) on the other. Flakes and cores rarely appear in the same phase (the exceptions are Phases $2 \mathrm{~B}$ and 6 ), while utilised fragments (Table 20.4) only occur in Phase 6 contexts and in the garden soil that stratigraphically represents Phases 4-6. Retouched flakes are present $(n=4)$, but there are no recurring tool forms. This is a feature of the New Guinea highlands flaked stone assemblages of the last 10,000 years, which are characterised by progressively fewer retouched flakes (White 1977: 23; Evans and Mountain 2005: 371).
When reading what now follows, readers should refer to the corresponding classes of the previous section, when specific items are under discussion.

\section{Flakes (Table 20.2)}

There are 12 flakes overall. Complete flakes $(\mathrm{n}=4)$ are small: weight range $5-22 \mathrm{~g}$; axial length range $18-30 \mathrm{~mm}$. Retouched flakes $(\mathrm{n}=4)$ are also small: weight range $1-26 \mathrm{~g}$; axial length range $12-23 \mathrm{~mm}$. Retouched flakes are present in early and late phases. Two of the oldest flakes in the collection (from Phase 1) have retouch, which is probably an edge-sharpening technique modifying the cross-section and unrelated to modifying the general shape (plan view) of the tool. Fine retouch on flake K/72/S125 may have been for shaping a sharp distal tip, where usewear is most developed. A Phase 6 retouched flake, K/77/S42 (Figs 20.16C and 20.16D), has a steeply retouched (backed) edge that might have facilitated holding or hafting. Flakes were used for scraping and cutting soft starchy plants and wood. The processing of starchy plants is less well represented in Phases 4-6 than in Phases 1-3.

\section{Cores (Table 20.3)}

Cores ( $\mathrm{n}=12$, weight range $11-1250 \mathrm{~g}$ ) are generally larger than flakes. The longest scars on cores range from $8 \mathrm{~mm}$ to $35 \mathrm{~mm}$, compared with flake tool axial lengths ranging from $12 \mathrm{~mm}$ to $34 \mathrm{~mm}$. Cores are likely to have been used both to create flakes and to be utilised themselves as implements for cutting and scraping starchy plants and wood. The longest flake scar on any of the five smallest cores (weight range: $5-36 \mathrm{~g}$ ) is less than $12 \mathrm{~mm}$, suggesting that flaking of these small cores was not to produce flakes for use, but rather to sharpen and shape core edges for use.

\section{Utilised fragments (Table 20.4)}

Utilised fragments $(n=7)$ range in weight from $1 \mathrm{~g}$ to $185 \mathrm{~g}$ and in length from $17 \mathrm{~mm}$ to $30 \mathrm{~mm}$. Utilised fragments were only found in contexts associated with either the Phases 4-6 
grouping or Phase 6. The three largest tools (weight range 63-185 g), all from Phases 4-6, are naturally sharp-edged slate or basalt fragments. The four smallest tools (weight range 1-16 g), all from Phase 6, are chert fragments. Utilised fragments were mostly employed in cutting and scraping starchy plants and wood. One utilised fragment (K/77/S76) had possible blood traces identified by Tom Loy.

During the period of garden soil formation that stratigraphically represents Phases 4-6, one utilised fragment of slate $(\mathrm{K} / 72 / \mathrm{S} 6)$ may have been used for digging the soft swamp sediments, though with fewer striations and less bright polish than commonly found on other sod cutting and digging implements (e.g. van Gijn 1990: 46, 48; Yerkes et al. 2003). The suitability of PNG slate for such tasks has not been tested experimentally as it has elsewhere for other stone (e.g. quartz, see Rots and van Peer 2006). The nature of the local peaty sediment may partially explain the lack of striations and local tool-use experiments need to be undertaken to evaluate this proposition raised by Allen $(1970,1972)$ and discussed by Golson (1977c: 159-160) and Bulmer (2005: 425-426).

\section{Grinding and pounding stones (Table 20.5)}

Upper and/or lower grinding/pounding stones $(\mathrm{n}=14)$ are present in all phases and nearcomplete implements $(\mathrm{n}=6)$ range in weight from $239 \mathrm{~g}$ to $1740 \mathrm{~g}$. Phase 1 has an unmodified elongated cobble $(\mathrm{K} / 75 / \mathrm{S} 178)$ used as a pestle for pounding Dioscorea yam and other starchy plants. There is also, from the grey clay between Phases 1 and 2, a fragment of a very smooth grinding stone (K/77/S34) symmetrically shaped and described as from a stone bowl (Golson 2000). In Phase $2 / 3$, a lower grinding stone (K/75/S145B) has evidence of starchy-plant processing. The pounding stones were used for grinding and pounding starchy tubers, with likely hammerstone, anvil and ochre-grinding functions as well in early phases. In Phases 6, there are three artefacts with numerous broad striations and flat or concave surfaces, K/72/S57, K/73/S68 and $\mathrm{K} / 77 / \mathrm{S} 46$, which are probably whetstone fragments.

\section{Axes (Table 20.7)}

Ground and polished axes in the collection under review are represented by fragments of and flakes from the original implements. With one possible exception, they make their appearance in Phase 5 (1 fragment, 1 flake) and more prominently in Phase 6 (5 fragments, 5 flakes). As discussed in the previous section (Fig. 17.3), it can be seen that nine out of the 10 Phase 6 specimens and one of the two from Phase 5 are closely connected with habitation areas, in many cases individual houses. The two pieces not so connected are both fragments.

The possible exception referred to above is $\mathrm{K} / 75 / \mathrm{S} 193$, which is described as belonging to Phase 3. It was found at the base of a late Phase 3 tributary channel under investigation in excavation trenches shown in Figure 13.7 (specifically see A). It was made of a different stone from all the other axe pieces in the collection, a volcanic rock so weathered that its interpretation as an axe fragment is uncertain. As a result, it is not considered further in this discussion.

Of the remaining 12 axe fragments and flakes from Phase 5 and Phase 6, at least 10 have traces of plant tissue — starch, cellulose, phytoliths_ on polished surfaces (Table 20.7). In at least two instances (K/77/S57 and 67 of Table 20.7), ribbons of smeared fibrous woody tissue are remarkably similar to microscopic traces observed by Fullagar on experimental axes used in a study of axe making in the Wahgi by John Burton (1984: Chapter 6). The residues are mostly embedded in a waxy coating and could not be removed in water by pipette or ultrasonic cleaning. With further analysis, it may be possible to distinguish residues from hafting and use and to take samples of them for radiocarbon dating. 
Six flakes and one fragment have been recycled as tools with traces indicating use as wood scrapers (some probably hafted as small scrapers) and one cutting implement. One of the flakes is from Phase 5, the others, including the fragment, are from Phase 6.

Two significant features of the 12 axes under study are pointed out above: their first appearance in Phase 5 and their close association with houses and habitation areas. Both are confirmed by information from John Burton (1984: 296), who made use of 31 excavated items of which 28 are no longer available following the bush fires (see Chapter 21, section 'Axe distributions at Kuk'). Burton's work on sourcing the raw material of the 31 axes in question supplies a third and most important dimension to the Kuk material: the fact that all of them, with one exception, are of foreign origin, made of stone from specialised quarries and widely distributed through the mechanism of trade and ceremonial exchange (see Tables 21.2 and 21.4). The excavated fragments can sometimes be large enough to reveal something of the typology of the original specimens, like the planilateral axes of the Jimi quarries with transversely curving surfaces and narrow flat sides and the quadrangular-sectioned axes of the middle Wahgi quarries, thicker and flatter of surface (Burton 1984: 112-113, Fig. 6.1). Examples of the two classes of axe are illustrated in Chapter 21, a Jimi axe (Fig. 21.4) and a Tuman axe (Fig. 21.3).

\section{Artefact classes over time}

Despite the low numbers of artefacts that have survived (Table 20.1), it may be possible to distinguish Phases 1-3 from those that followed on the basis of stone artefact classes and archaeological context. The tools from Phases 1-3 (six flake tools of Table 20.2, seven core tools of Table 20.3 and seven grinding/pounding stones of Table 20.5) were all recovered from garden areas in the southeastern corner of the site, while the great majority of Phase 6 tools (Table 20.1) came from houses or housing areas. These included all four flake tools (Table 20.2), all three core tools (Table 20.3) and two out of three of the grinding/pounding stones (Table 20.5), as well as nine out of 10 axes (Table 20.7) and all four utilised fragments (Table 20.4), two classes of tool that appear for the first time in Phase 6. The same could be true of Phase 5, there is the first evidence of housing in the swamp, though artefact numbers are too few to show. There are four catalogued artefacts (Table 20.1), of which two, a club head fragment (Table 20.6) and a recycled flake from an axe (Table 20.7), were found in the house ditches of neighbouring structures $P$ and Q beneath the Phase 6 housing area at the north end of block A9g (see Fig. 17.3). The other two, part of an axe blade edge (Table 20.7) and a grinding/pounding stone (Table 20.5), had no evident association with a house or housing area (see Phase 5 house distributions in Fig. 15.4).

Apart from axes, there are remarkable similarities across phases. The range of functions for cores, flakes and utilised fragments appears to overlap considerably through time, mainly covering the cutting and scraping of soft starchy plants and wood. The grinding and pounding stones have similar functions, although there are differences: hammerstones, an anvil and a possible ochre grater were identified in early phases, while possible whetstones for grinding axes were, expectedly, only found in Phase 6. The low frequency of artefacts in Phases 1-3, from large excavations, where some of the stone finds had not been returned to store before the 2003 bushfires, suggests that the artefacts were not close to stone-knapping areas. Rather, the implements are most likely to be associated with expedient maintenance tasks and some food preparation. A possible context for stone tool tasks in Phases 1-3 would be places where fieldworkers cultivated the gardens, sharpened and repaired wooden implements of various kinds (cf. Chapter 19) and occasionally prepared food, including yam and taro, out in the fields. 
The long period between the beginning of Phase 4 around 2000 years ago and the appearance of housing in the swamp in Phase 5, say 500 years ago, is poorly served with artefactual evidence (see Table 20.1). As discussed, there are four artefacts catalogued for Phase 5, which is thought to have started about AD 1250. There is one stone artefact catalogued between Phases 4 and 5 and two for Phase 4. There are six artefacts in the composite grouping Phases 4-6, established to include material from the garden soil complex that could not be allocated to one of the three phases of swamp drainage and cultivation within it. Two of these are core tools (Table 20.3) and a third is a grinding/pounding stone (Table 20.5), none with any obvious housing connection. The other three are utilised fragments (Table 20.4), a class otherwise only represented in Phase 6. Two of these artefacts may be connected with housing areas: the slate fragment K/72/S6 with the houses at the northern end of blocks A9g and A9h and the other item, K/75/S30, on the fringe of houses on drains C9f/g and C9g/h. We may note that the Phases $4-6$ collection does not include any axe fragments or flakes (Table 20.1).

It can be argued that the distribution of artefacts across phases at Kuk is affected to some degree by the excavation strategies employed. Thus, the relative abundance of artefacts attributable to Phase 6 might be explained by the targeted investigation of a small number of the many house sites that were prominent surface features from that period and the exposure of similar house sites to disturbance by the digging of Station drainage lines (see in particular Fig. 17.3). In fact, the presence of large numbers of houses in the eastern part of the Station during Phase 6 is seen as related to a massive change in the organisation of landuse there with the adoption of the sweet potato (Ipomoea batatas) as a staple in the upper Wahgi by around AD 1700 (Chapter 16). It is true that there were Phase 5 houses in the swamp, probably late in the phase, around AD 1500. Only a few were found because they were not necessarily visible at the surface and were difficult to identify in drain walls (see Chapter 15, section 'Artefacts, houses and pigs'). However, it is also likely that they were not common in a situation where the whole of the eastern half of the site was under drainage for gardening. As far as is known, there were no houses in the swamp in early Phase 5 or Phase 4.

However, there is another reason, besides the absence or fewness of house sites, for the low numbers of artefacts that can safely be allocated to Phases 4 and 5. This is that in both phases the minor ditches subdividing drained areas into garden plots were dug to a grid pattern. This made it possible to reconstruct the organisation of a gardening system and its changes over time, from the profiles of these minor ditches in the Station drain walls that cut across them at regular intervals. As is clear from Chapters 14 and 15, this made it unnecessary to excavate the lines of ditches over wide areas. This was even more the case with Phase 6 , where the ditches were visible as depressions at the surface of the swamp. Large-scale disturbance of surface layers at Kuk was not something that the Research Station management would have permitted in the early years of the Project, until it became obvious from its work that Kuk had been thoroughly disturbed by ditch digging and gardening during previous millennia. The large-scale excavations that became possible from the mid-1970s is reflected in the total numbers of objects recorded in Table 20.1 for Phases 1, 2 and 3 as compared with Phases 4 and 5.

The transition from waisted axes to ground and polished stone axes in Papua New Guinea is linked with tool design, hafting technology and forest clearance for cultivation in the Holocene (Golson 2005: 451-452). Waisted axes and edge-ground axes (see Bulmer 2005; Golson 2005) are one of several potential archaeological indicators of constituent practices (e.g. forest disturbance) and plant exploitation that can be documented in the upper Wahgi Valley spanning at least 30,000 years (Denham, Fullagar and Head 2009: 37). In the new circumstances of the ground and polished stone technology that started at Kuk in Phase 5, there is clear evidence of more intensive use of artefacts; six axe flakes and one fragment were recycled, all belonging to Phase 6 except for 
one flake from Phase 5 (Table 20.7). Despite this evidence of recycling and the stone working associated with it, there still appears to be relatively little primary flaking of stone on-site and the use of several edges also seems to be common. Multifunctional tools used on more than one plant species or in different modes of use have been identified in earlier phases (e.g. in Table 20.3, the core tool K/75/S179 from the grey clay between Phases 1 and 2).

No animal residues were found on any artefact, apart from possible blood residues on utilised fragment K/77/S76 from Phase 6. Starch grains are reported for four artefacts: K/77/S46 from Phase 6, which is a grinding/pounding stone with one grain; and three artefacts in the Phases 4-6 grouping, K/72/S6 and S51 (Table 20.4) and K/72/S26 (Table 20.3). The grains have not been taxonomically identified, but there is no good match with taro, yam or sweet potato (Loy, Spriggs and Wickler 1992; Horrocks et al. 2004; cf. Fullagar et. al. 2006;).

A possible scenario is that stone tool tasks in the housing era at Kuk Swamp were undertaken in places close to where woodworking tools were used and repaired, sometimes involving edge grinding and the use of small woodworking tools to prepare wooden hafts and to manufacture other wooden implements. There is also evidence that axe flakes were recycled to make small woodworking tools. More intensive woodworking activity distinguishes the tools of the housing period from those in Phases 1-3.

\section{Conclusions}

Fifty-eight stones (30 per cent of the 149 examined microscopically) have signs of use. All flakes and cores have traces of edge utilisation. Stone tool use was related primarily to processing wood and other plants, including cultivated food plants (e.g. Dioscorea sp. yam and Colocasia esculenta taro in Phase 1, 10,000 years ago). It is likely that different starch grain assemblages relate to different contexts and tasks during Phases 1-3 (in the gardens/fields with more food-processing activities and one possible instance of digging peat) compared with Phases 4-6 (near houses with more woodworking activities). Further work is needed both in taxonomic identification of starch grains and in experimental studies to evaluate certain wear patterns that have not yet been characterised for the study area.

Evans and Mountain (2005: 367) have argued that although functional studies have been successful in identifying tool use and resource use in highlands flaked stone assemblages, the study of tool edges (e.g. White 1972) and of use-wear and residues (e.g. Fullagar 1989) has failed to overcome the problem of dealing effectively with apparently amorphous stone artefacts. They have promoted (Evans and Mountain 2005: 368-369) the concepts of risk and provisioning as a means to explain change in artefact form, with a transition identified between the Pleistocene (provisioning of individuals) and late Holocene (provisioning of place). At the highlands rockshelter of Nombe, they found early Holocene volcanic cores in all stages of reduction (indicating provisioning of place) and chert only in later stages of reduction (indicating mobility and provisioning of individuals). They found no such dichotomy in the Pleistocene. This they interpret as indicating a trend from provisioning individuals to provisioning place.

Although artefact frequency is too low at Kuk to permit statistical analysis, volcanic flaked stone is rare in all phases while volcanic grinding stones are present in all phases. Retouched chert flakes and cores are present in all phases. Utilised chert fragments are only present in Phase 6. Following the Evans and Mountain logic, the grinding stone material can be interpreted as a strategy to provision place. Volcanic stones were brought up from the river and utilised in various ways - grinding, pounding, cooking — and the stones could be recycled. The chert artefacts were brought in as small flakes, fragments, cores and retouched tools, suggesting later stages 
of reduction. In contrast, the largest core $(\mathrm{K} / 75 / \mathrm{S} 179)$ is made on a volcanic rock, which is an order of magnitude heavier than any chert artefact and which suggests provisioning of place for subsequent use. The Kuk assemblage indicates provisioning individuals with chert, as flake and core tools, and provisioning place with volcanic stone, in the form of grinding, pounding and cooking stones, and a single large core. Provisioning of place from the early Holocene at Kuk seems to be consistent with the Nombe flaked stone patterns identified by Evans and Mountain (2005: 380), marking a transition between the Pleistocene and the late Holocene and indicating more sedentary living patterns.

\section{Acknowledgements}

Part of this research published previously (Fullagar et al. 2006) was undertaken in collaboration with Judith Field (then University of Sydney, now University of New South Wales) and Carol Lentfer (University of Queensland), who provided expertise on phytolith and starch grain identification. For comments and direction since embarking on the study of selected Kuk artefacts in 1999, we are indebted to Tim Denham (then Monash University, now ANU) and Tom Loy (1942-2005) who laid the groundwork for this study in 1991. Adam Black (ex-ANU) is especially thanked for photography and image analysis of artefacts salvaged from the Weston store after the 2003 bushfires. Thanks also to David Ellis, Philip Hughes and Marjorie Sullivan for advice on tool stone terminology. 


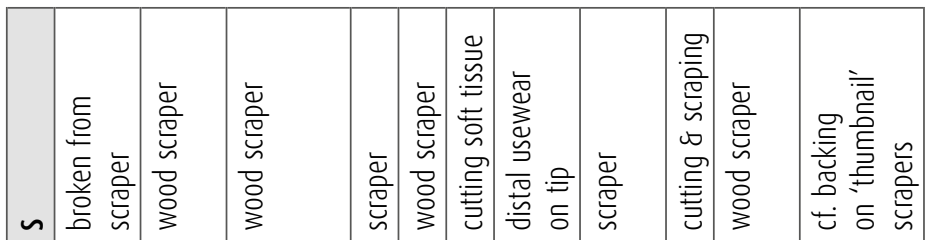

$\simeq$ 읃 은 은 $\cong$ 읃 읃

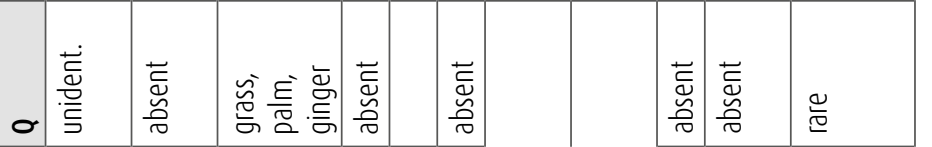

蓠

\begin{tabular}{|c|c|c|c|c|c|c|c|c|c|c|c|}
\hline 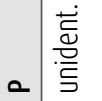 & 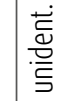 & 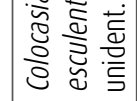 & $\mid \begin{array}{c}\overrightarrow{\bar{\nu}} \\
\stackrel{\tilde{\sigma}}{\sigma}\end{array}$ & 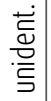 & $\begin{array}{l}\overrightarrow{\bar{\nu}} \\
\stackrel{\tilde{\sigma}}{\sigma}\end{array}$ & 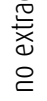 & 这 & & & 芯 & 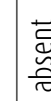 \\
\hline & in & 으 & & $\stackrel{8}{q}$ & & $\stackrel{\sim}{\sim}$ & & & & 으 & ભ \\
\hline
\end{tabular}

के

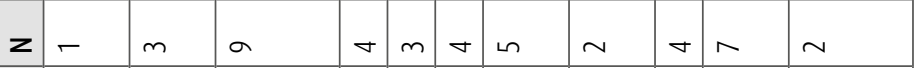

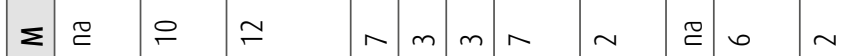

\begin{tabular}{|c|c|c|c|c|c|c|c|c|c|c|c|}
\hline z & $\widetilde{\complement}$ & - & \ulcorner & $\sim$ & $m$ & m & r & $\sim$ & ᄃ & 6 & $\sim$ \\
\hline - & $\stackrel{\Xi}{\Xi}$ & $\mp$ & $\approx$ & ¿ & Ln & $\infty$ & $F$ & $\infty$ & $\stackrel{\widetilde{E}}{E}$ & $\stackrel{\infty}{\stackrel{\infty}{2}}$ & เn \\
\hline$\simeq$ & 恶 & $\stackrel{\circ}{\circ}^{\circ}$ & $\stackrel{ }{\sim}$ & $\simeq$ & $a$ & $\sim$ & $\simeq$ & $\nabla$ & $m$ & $\infty$ & $m$ \\
\hline
\end{tabular}

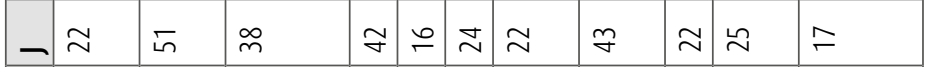

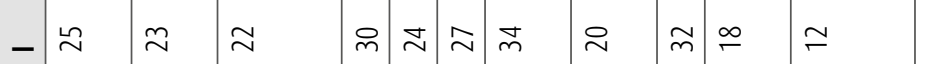

৬ $\simeq$ On

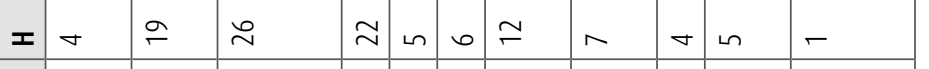

党 总 总

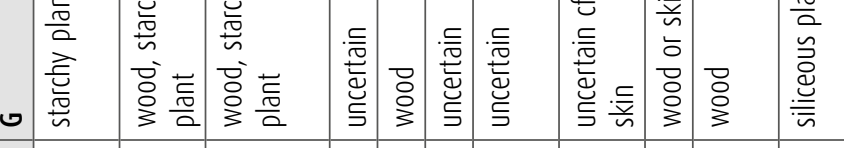

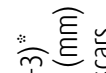

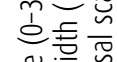

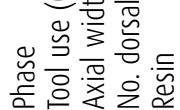

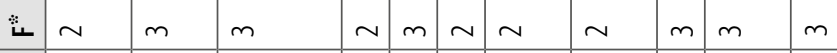

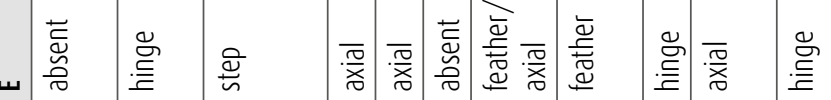

$\infty \leftarrow-z \propto$

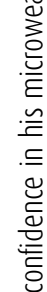

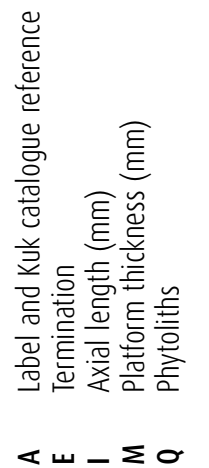

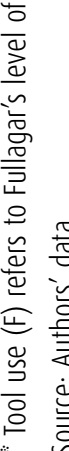

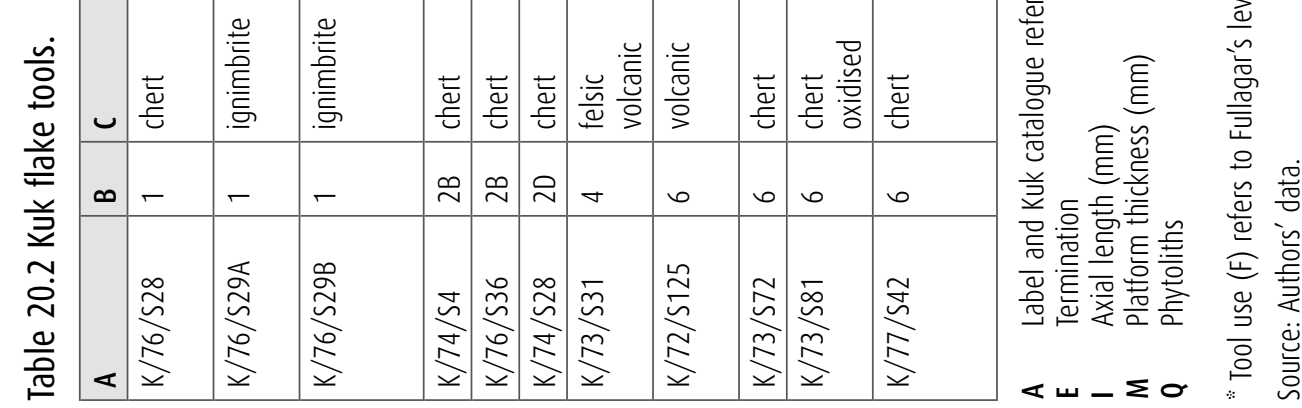




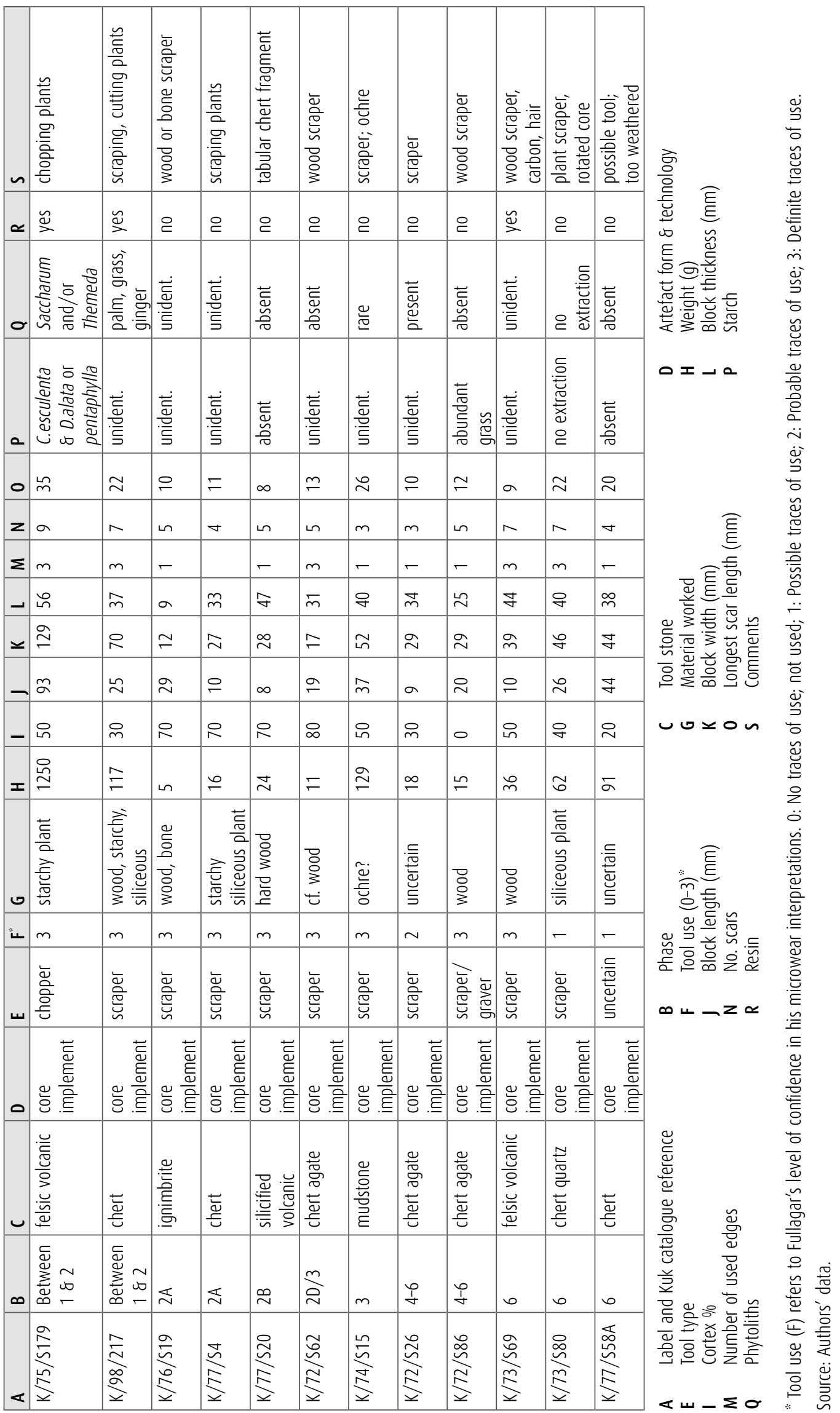




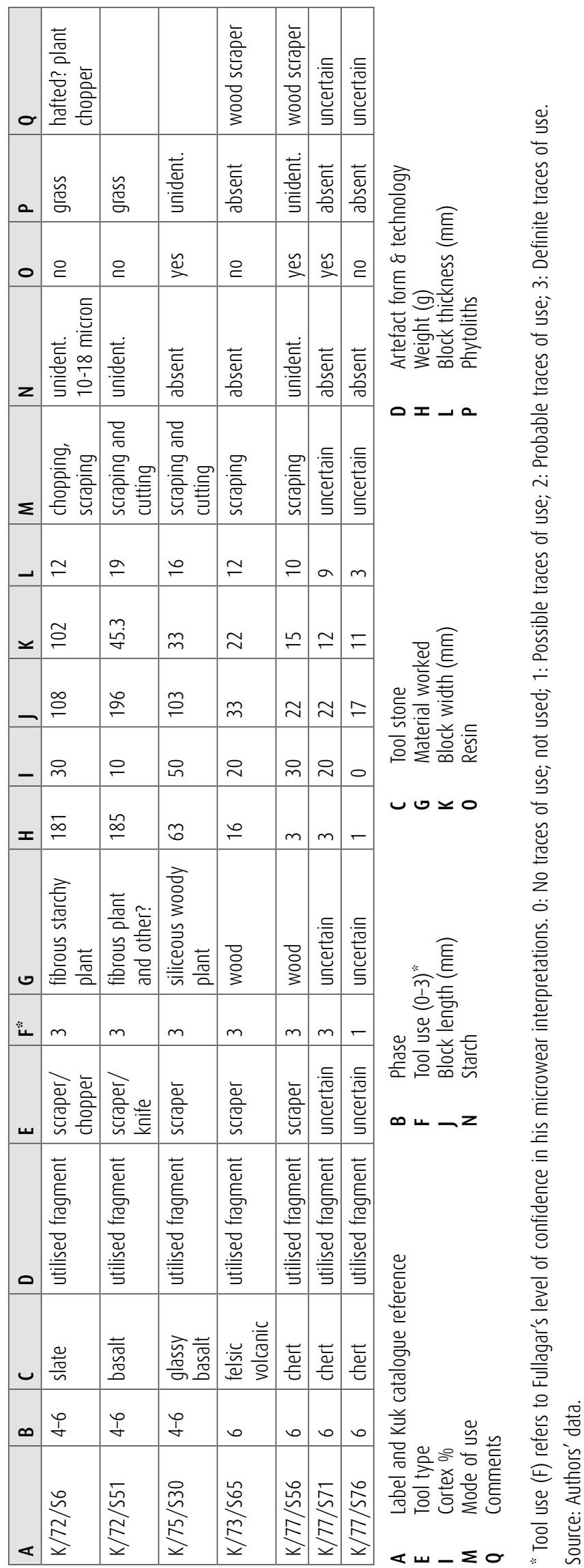




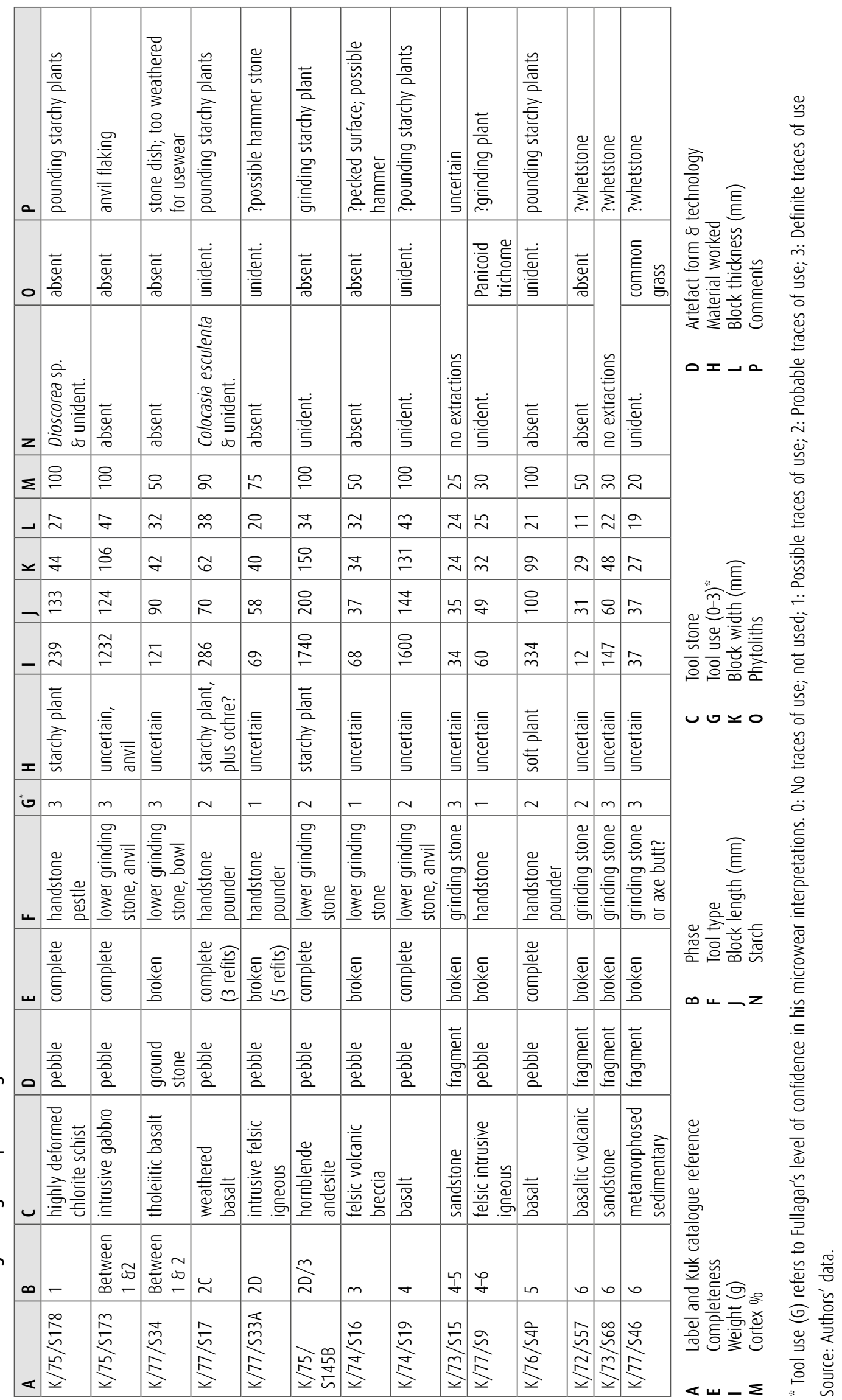




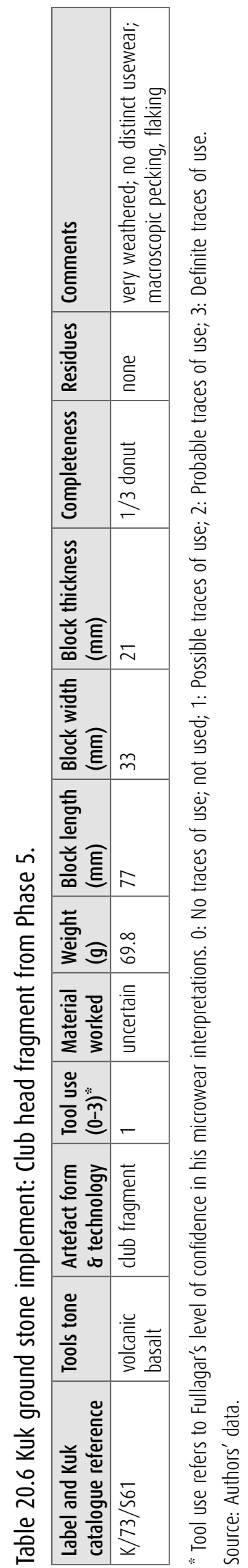

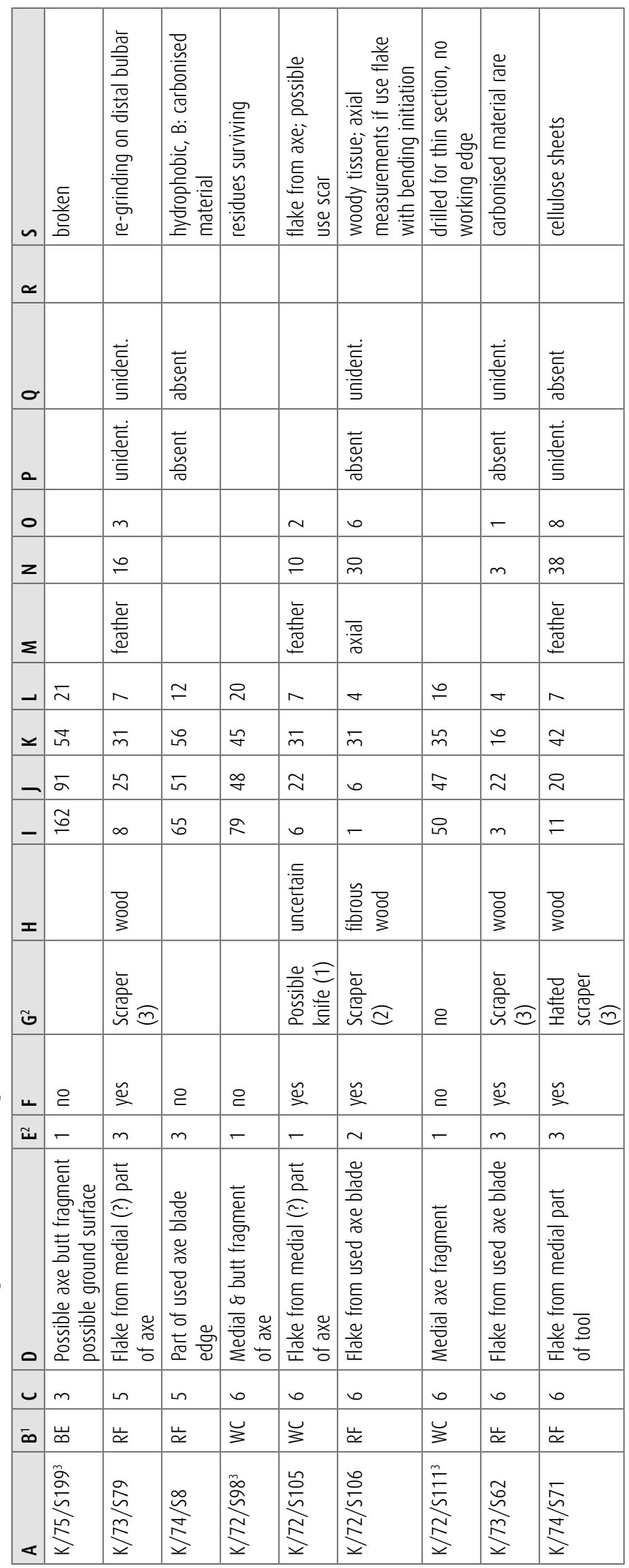




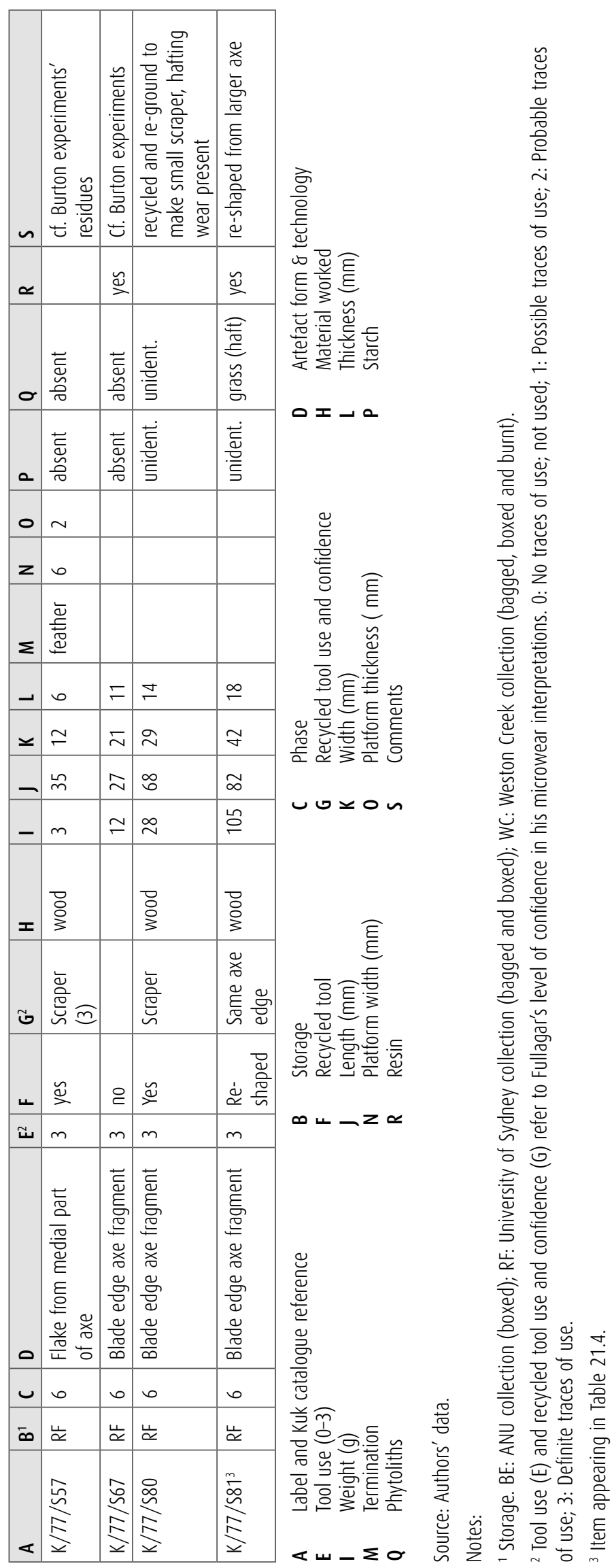


This text is taken from Ten Thousand Years of Cultivation at Kuk Swamp in the Highlands of Papua New Guinea, edited by Jack Golson, Tim Denham, Philip Hughes, Pamela Swadling and John Muke, published 2017 by ANU Press, The Australian National University, Canberra, Australia. 